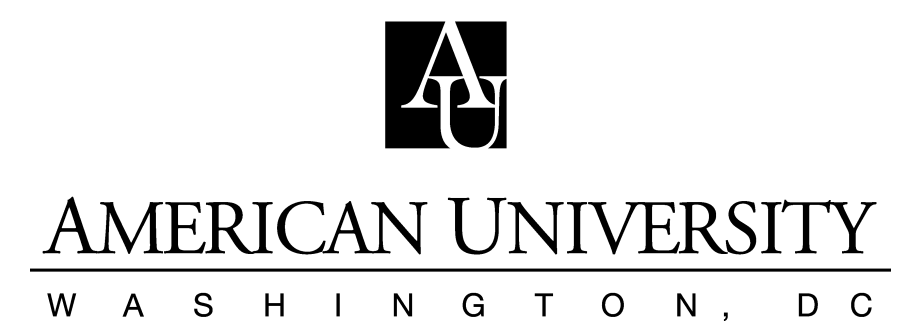
Department of Economics Working Paper Series

\begin{tabular}{|c|}
\hline $\begin{array}{l}\text { Legal Rules and Bankruptcy Rates: } \\
\text { Historical Evidence from the States }\end{array}$ \\
\hline by \\
\hline $\begin{array}{c}\text { Mary Eschelbach Hansen } \\
\text { Bradley A. Hansen }\end{array}$ \\
\hline $\begin{array}{c}\text { No. } 2006-16 \\
\text { December } 2006\end{array}$ \\
\hline
\end{tabular}

http://www.american.edu/cas/econ/workpap.htm

Copyright (C) 2006 by Mary Eschelbach Hansen and Bradley A. Hansen. All rights reserved. Readers may make verbatim copies of this document for non-commercial purposes by any means, provided that this copyright notice appears on all such copies. 


\title{
Legal Rules and Bankrutpcy Rates: Historical Evidence from the States ${ }^{*}$
}

\author{
Mary Eschelbach Hansen \\ Bradley A. Hansen ${ }^{* *}$
}

\begin{abstract}
Since the early twentieth century, observers have attributed the wide variation in state bankruptcy rates to variation in state legal rules such as garnishment and bankruptcy exemptions. Recent econometric analyses, however, conclude that legal rules do not matter. We explore the impact of legal rules on bankruptcy rates using a new technique-fixed effects vector decomposition-to exploit historical variation in legal rules. The technique allows us to estimate the impact of timeinvariant legal rules in a fixed effects framework. We find that the variation in state legal rules explains much of the variation in state wage earner bankruptcy rates for 1926 to 1932.
\end{abstract}

Key words: Bankruptcy, fixed effects vector decomposition, law and economics

\section{JEL classification: $\mathrm{N} 4, \mathrm{~K} 4$}

\footnotetext{
* [Insert acknowledgements and other information]

** Department of Economics, American University and Department of Economics, University of Mary Washington. Contact: Mary Eschelbach Hansen, Department of Economics, American University, 4400 Massachusetts Avenue, NW, Washington, DC 20016-8029. Email: mhansen@american.edu.
} 
Legal Rules and Bankruptcy Rates:

Historical Evidence from the States

In 2005, after nearly a decade of lobbying by consumer creditors, Congress passed the Bankruptcy Abuse Prevention and Consumer Protection Act. ${ }^{1}$ The Act was intended to reduce the bankruptcy rate by reducing the benefits of filing for bankruptcy. The premise underlying the Act is central to law and economics: changes in the law can cause changes in the choices people make. There is, however, considerable disagreement over the extent to which legal rules, as opposed to economic or social factors, influence the decision to file for bankruptcy. For instance, although the increasing bankruptcy rate in the 1980s was initially attributed to the Bankruptcy Reform Act of 1978 (Shepard, 1984; Boyes and Faith, 1986), later research raised doubts about this conclusion (Domowitz and Eovaldi, 1993), and the bankruptcy rate continued to rise despite 1984 amendments intended to make bankruptcy less attractive.

Although bankruptcy is a federal law, states determine what property is exempt from collection. ${ }^{2}$ States also regulate the alternatives to bankruptcy, that is, the types of non-bankruptcy collection procedures that creditors may use. Since the early years of the twentieth century variation in these legal rules has been cited as one of the primary causes of variations in state bankruptcy rates (e.g. U.S. Department of Justice, 1905), but several econometric analyses of variations in state bankruptcy rates have called into question the importance of these legal rules (Shiers and Williamson, 1987; Buckley and Brinig, 1998; Weiss et al., 2001). Lawrence Weiss, Jagdeep Bhandari and Russell Robins (2001:419), for example, conclude that, “manipulation of a particular state's legal rules-for instance, by altering personal exemption levels in bankruptcy or by changing the

\footnotetext{
${ }^{1}$ Pub. L. No. 109-8, 119 Stat. 23. See Nunez and Rosenthal (2004) on the political economy of creditors' lobbying activities.

2 The Bankruptcy Reform Act of 1978 created federal exemptions, but states still determine whether or not their citizens are allowed to use these federal exemptions or required to use exemptions specified by the state..
} 
percentage of wages subject to garnishment outside of bankruptcy-is unlikely to have much impact on the number of bankruptcies filed in that state." These studies conclude that the variation in state bankruptcy rates is attributable to variation in economic and social variables rather than legal rules.

It may be the case that the historical emphasis on legal rules was misguided, but there are two reasons to suspect that existing studies underestimate the influence of legal rules. The first reason is that the existing studies using panel data employ fixed effects (Weiss et al., 2001; Buckley and Brinig, 1998). The methodological problem in using fixed effects to study the influence of legal rules on bankruptcy rates is that the rules are fairly stable over time. Fixed effects absorb the impact of these time-invariant variables (Hausman and Taylor, 1981). As Michelle White (2006) observed regarding Frank Buckley and Margaret Brinig's analysis, "the state dummy variables capture the effect of the states' initial exemption levels, while the exemption variables themselves capture the effect of changes in exemptions." Not surprisingly, then, the studies that employ fixed effects models tend to conclude that legal rules do not matter.

The second reason to suspect that recent studies underestimate the influence of legal rules is that they use data from the 1980s and 1990s. Since the late 1960s federal legislation and court decisions have restricted state collection laws, reducing the state-to-state variation in legal rules. For example, by the 1990 s more than two-thirds of states had wage exemptions set at the federal minimum.

To remedy these problems we combine a new econometric technique with historical data. We use a technique developed by Thomas Pluemper and Vera Troeger (forthcoming) that allows us to estimate the importance of time-invariant legal variables within a fixed effect framework. We apply their fixed effect vector decomposition procedure in the estimation of state wage earner bankruptcy rates during the years 1926 to 1932, when greater variation in state legal rules existed. Also, for this period there exists a measure of the severity of garnishment law that takes into 
consideration procedural aspects of the law as well as the level of wage exemption. Thus, our method and data are well-suited to an inquiry of the extent to which legal rules can influence bankruptcy rates.

We find a strong relationship between bankruptcy rates and legal rules, especially laws regarding garnishment and the maximum legal interest rate, and, to a lesser degree, exemptions in bankruptcy itself. We further find that variables measuring social capital, such as church membership, have great influence on the bankruptcy rate.

\section{Institutional Background: Bankruptcy, Exemptions and Garnishment}

The origins of American bankruptcy law can be traced to the first English bankruptcy law enacted in 1542. Bankruptcy law provides an alternative to traditional creditors' remedies, which are referred to as "first-come, first-served" or "grab" laws because the priority of claims is determined by the order in which creditors take legal action. Bankruptcy law, in contrast, provides for the liquidation of the debtor's assets and a pro rata distribution of the proceeds among like creditors. Although many people now regard the debtor's discharge as a central feature of bankruptcy law, discharge was not introduced until 1705 (Tabb, 1991). These two features—the equitable distribution of the debtor's assets among creditors and the discharge of the debtor-are the defining characteristics of Anglo-American bankruptcy law.

In the United States bankruptcy law is federal law. The Constitution specifically empowers Congress to enact uniform laws on bankruptcy. ${ }^{3}$ Congress, however, did not exercise this power for most of the nineteenth century. A law was passed in 1800 and repealed in 1803. A second law was passed in 1841 and repealed in 1843. A third law was passed in 1867 and repealed in 1879. A

\footnotetext{
${ }^{3}$ Warren (1935) was the standard reference on the history of bankruptcy law in the United States for over fifty years, but in the last two decades the history of American bankruptcy law has been rewritten. See for example Balleisen (2001), Carruthers and Halliday (1998), Hansen (1998; 2000), Hansen and Hansen (forthcoming), Mann (2003), Sandage (2005), and Skeel (2001).
} 
permanent law was passed in 1898. The 1898 Bankruptcy Act remained in effect until it was replaced by the Bankruptcy Reform Act of 1978 (also known as the Bankruptcy Code, or simply the Code). ${ }^{4}$

Although several amendments were enacted between 1898 and 1926, the law that was in effect during the period we study was essentially the law passed in 1898. The 1898 Bankruptcy Act allowed creditors to petition the court to begin bankruptcy proceedings against a debtor (involuntary petitions), and the Act allowed debtors to petition for bankruptcy (voluntary petitions). Creditors were barred, however, from filing petitions against wage earners or farmers.

Procedure subsequent to the petition was the same in all cases. Other collection actions, such as garnishment, were stopped; a meeting of creditors was called; the debtor's non-exempt assets were liquidated and the proceeds were distributed on a pro rata basis among like creditors. The debtor could then apply for a discharge. Usually only fraudulent or illegal behavior prevented a discharge. ${ }^{5}$

Although the 1898 law was entitled "An Act to Establish A Uniform System of Bankruptcy," it did not bring about complete uniformity across the states. Prior to 1898 most states had already enacted exemption laws that placed limits on the property that could be taken to satisfy a creditor's claim. The 1898 Bankruptcy Act allowed states to determine the level of exemptions that would apply in bankruptcy as well. States typically defined both homestead exemptions and personal property exemptions. Most states defined homestead exemptions in dollars, but some states specified exemptions in terms of a quantity of land (see Appendix A). By the 1930s about two-thirds of states defined personal exemptions in dollars, but 13 states exempted only an itemized list of assets, such as family Bibles, items of clothing, and tools of the trade.

\footnotetext{
4 Pub. L. No. 95-598, 92 Stat. 2549.

5 Repayment plans for people with regular income (Chapter 13) and corporate reorganization (Chapter 11) were incorporated into bankruptcy law in the 1930s. The 1898 Act did contain a provision for compositions between debtors and creditors, but the provision was rarely used.
} 
States rarely changed exemptions. Table 1 shows homestead exemptions in 1883, 1920 and 1932 (Goodman, 1993; Wickens, 1936; see also National Association of Credit Men, various years). Only seven states changed homestead exemptions in half a century; only two states changed homestead exemptions between 1920 and 1933. The stability of exemptions is important for the analysis of bankruptcy rates because it suggests that exemption laws are not influenced by bankruptcy rates and can be treated as exogenous. Research on exemption levels in the 1990s supports this conclusion; the only variable that had a significant influence on the exemptions a state had in the 1990s was the exemptions the state had in 1920 (Hynes et al., 2001).

In the Code, Congress attempted to create greater uniformity in exemptions by establishing a federal exemption and allowing petitioners to choose between the federal exemption and their state's exemption. However, the Code also gave states the right to opt out of this dual system. If a state opted out, petitioners in the state had to use the state's exemptions. By 1990, all but 13 states had opted out. Congress had a small degree of success in promoting greater uniformity, but exemption levels in bankruptcy continue to be determined primarily by the states.

In contrast to its limited influence on exemptions in bankruptcy, the federal government has had considerable influence on garnishment law. Garnishment is the most important legal collection tool for creditors when wage earners default (White, 1998:212). Garnishment allows a creditor to obtain assets that belong to the debtor but that are in the hands of a third party. Garnishment can apply to bank accounts or other assets, but it is generally used to obtain wages that have not yet been paid.

State garnishment laws vary in the amount of wages that are exempted from collection and in how difficult it is to garnish someone's wages. In summarizing how the difficulty of garnishing wages varied between states in the 1930s, Rolf Nugent, John Hamm and Frances Jones (1936:2) explained: "In most States, garnishments are issued after judgment. In some states, however, a 
garnishment order may be issued simultaneously with the filing of the complaint by the creditor, and in others the garnishment may be issued only after a levy on property in execution of judgment has been returned unsatisfied." While some procedural differences may exist today, they are not captured in econometric analyses, which include only the easy-to-quantify level of wage exemption.

In the 1920s and 1930s, some states exempted all or most of the debtor's wages from garnishment while others exempted little from garnishment. The variation in garnishment law has been considerably diminished by the federal government. The 1968 Consumer Credit Protection Act limited garnishment to 25 percent of take-home pay or the excess of the debtor's take-home pay over 30 times the federal minimum wage. As of 1992, 34 states limited garnishment to the federal maximum of 25 percent (White 1998:208). In 1969, the Supreme Court also reduced some of the variation in garnishment by restricting the use of prejudgment attachments of wages (Sniadich vs. Family Finance Corporation 395 U.S. 337). In sum, the legal rules in the 1920s and 1930s exhibited greater variation than has been the case since the late 1960s. Exploiting historical data allows us to more accurately assess the extent to which state legal rules are capable of influencing the bankruptcy rate.

While the period under consideration has a number of feature to commend it, it might reasonably be questioned whether a data set that includes the beginning of the Great Depression could have any relevance for other periods. The years from 1926 to 1932 were, however, fairly typical for wage earner bankruptcy in the Twentieth Century. Figure 1 puts the period in context by showing the wage earner bankruptcy rate in the United States from 1899 to 1970. The 1920s marked the beginning of the long run trend of increasing bankruptcy rates that continued, with brief interruptions, into the Twenty-first Century. Rather than creating a crisis in wage earner bankruptcy the beginning of the Great Depression was one of these brief interruptions, as was the recession in the late 1930s. Analysis of wage earner bankruptcy rates from 1926 to 1932 will not directly answer 
questions about how people would respond to changes in current legal rules. The period should not, however, be regarded as an aberration so far as bankruptcy is concerned.

\section{Existing Evidence on Legal Rules and Bankruptcy Rates}

The effect of legal rules on the bankruptcy rate can only be determined empirically. To see why, decompose the bankruptcy rate $(r)$ into its component parts: $r=i \times d \times b$. The fraction of the population that petitions for bankruptcy is the product of the fraction of the population that is indebted $(i)$, the fraction of the indebted population that defaults $(d)$, and the fraction of the defaulting population that chooses bankruptcy $(b)$. The greater the supply of credit, the larger is the fraction of the population at risk for default and bankruptcy. Other things equal, larger exemptions decrease the expected profit for the creditor, but increase the expected benefit for the debtor. Consequently, higher exemptions increase the demand for credit but decrease the supply. Higher exemptions are therefore expected to increase the interest rate, but may increase or decrease the quantity of loans depending upon the relative size of the shifts in demand and supply. ${ }^{6}$ Thus theory offers no a priori prediction about how changing the cost of bankruptcy might alter the quantity of loans or the bankruptcy rate.

The effect of the severity of garnishment law is also ambiguous. Increasing the wage exemption in garnishment (making garnishment more lenient from a debtor's perspective) increases the probability that a defaulting debtor chooses garnishment rather than bankruptcy, and makes borrowing more attractive. But, because higher wage exemptions make lending less attractive, the net effect on the bankruptcy rate is unclear. If a state makes it easier for a creditor to garnish a debtor's wages, then the law becomes more severe from a debtor's perspective. Creditors may be

\footnotetext{
${ }^{6}$ Several recent studies have examined the effect of exemptions on the supply and demand for credit. High exemptions have a negative effect on the supply of credit to households (Gropp et al., 1997; Lin and White, 2001) and to small businesses (Berkowitz and White, 2004). Exemptions do not affect mortgage loans (Berkowitz and Hynes, 1999).
} 
more willing to lend, but debtors may be less willing to borrow. Similarly, the effect of differences in filing fees and other costs of bankruptcy, such as social stigma, can only be determined empirically because they cause the supply and demand for credit to move in opposite directions.

As the early reports on bankruptcy filings under the 1898 Bankruptcy Act came in, contemporary observers claimed that differences in state laws drove the differences in bankruptcy rates. In 1905, The Annual Report of the Attorney General laid the blame for Alabama's high bankruptcy rate on its collection laws, explaining that because of "a State statute affecting the right to attach or garnish wages or salary of the laboring class, hundreds of poor unfortunates with liabilities in many instances less than $\$ 500$, have been driven to seek relief under the Federal law as a matter of preservation" (U.S. Department of Justice, 1905:95). Throughout most of the twentieth century people continued to point to variation in state legal rules as the source of variation in state bankruptcy rates (e.g. Stanley and Girth, 1971). However, pinning down the statistical relationship between legal rules and bankruptcy rates proved difficult.

Studies using times series data attributed the rapid increase in the national bankruptcy rate after 1978 to a decrease in fees and an increase in exemptions associated with the enactment of the Code (Sheperd, 1984; Boyes and Faith, 1986). Part of the increase in the bankruptcy rate was likely due to changes in the way filings were counted and to macroeconomic changes (Domowitz and Eovaldi, 1993). Furthermore, the Bankruptcy Reform Act was not the only relevant legal change that occurred in the late 1970s. David Moss and Gibbs Johnson (1999) observed that in 1977 the Supreme Court ruled that laws prohibiting lawyers from advertising were unconstitutional, and in 1978 the Court ruled that usury limits on credit cards were determined by the state from which the card was issued not by the state in which the card holder lived. The first decision made people more aware of bankruptcy and bankruptcy lawyers. The second decision increased the supply of consumer credit. Both rulings would be expected to increase the bankruptcy rate. 
In early econometric studies using cross sections, garnishment laws and exemption rates in bankruptcy appeared to be important determinants of state and district bankruptcy rates (Apilado et al., 1978; Heck, 1981; White, 1987). Severe garnishment law (when a lower percentage of wages were exempt from collection) increased the bankruptcy rate. In general, lower exemptions in bankruptcy reduced the bankruptcy rate. Exemption levels also influenced the choice between Chapter 7 and Chapter 13 bankruptcy (White, 1998; Nelson, 1999). Recent studies used samples of credit card holders and reinforced the results from geographic cross sections. More severe garnishment law decreased the likelihood of default but increased the likelihood that a person who defaulted chose bankruptcy (Dawsey and Ausubel, 2002; Agarwal et al., 2003). Higher exemptions increased the likelihood that a person defaulted and filed for bankruptcy (Agarwal et al., 2003). The results are reinforced in a study of small business bankruptcy (Agarwal et al, 2005).

In contrast, several studies of bankruptcy rates in the 1980s and 1990s used panel data and failed to find a statistically significant relationship between garnishment law and bankruptcy rates (Shiers and Williamson, 1987; Weiss et al., 2001), or between exemption laws and bankruptcy rates (Buckley and Brinig, 1998; Weiss et al., 2001). These studies found that economic and social variables explained more of the variation in bankruptcy rates.

Buckley and Brining (1998) argued that holding traditional values regarding commitment and membership in a community decreased the bankruptcy rate by decreasing the likelihood of default. They posited that social capital was greater in more elderly and more Catholic populations, and that social capital was lower in more urban populations and populations with higher divorce rates. Their measures of social capital were correlated with the bankruptcy rate. ${ }^{7}$

However, the interpretation of these social capital variables is problematic. Membership in a religious group may, for instance, provide a place to turn to when things go wrong; church

\footnotetext{
7 These findings are consistent with recent work that shows the importance of relationship banking to the supply of
} credit to the poor (Holmes et al 2005). 
membership provides insurance against decreases in consumption when income falls (Dehejia et al., 2005). The life-cycle theory of savings suggests that older populations would be less indebted and have lower bankruptcy rates regardless of their beliefs about commitment. Divorce, like poor health, negatively affects the household balance sheet (Warren and Tyagi, 2003; Lyons and Yilmazer 2005).

Because of the difficulty of measuring social capital directly, some authors looked at the dynamic effects of bankruptcy filings to infer the effect of social capital. For example, other things equal, households became more likely to default as the bankruptcy rate rose during the 1980s (Gross and Souleles, 2002), and individual households were more likely to file for bankruptcy in states that had higher bankruptcy rates in the past (Fay et al., 2002). These patterns are consistent with the idea that the social stigma of bankruptcy fell as bankruptcy became more common, but they are also consistent with the idea that increased information about bankruptcy lowered the cost of filing. ${ }^{8}$

A final vein of research emphasized economic variables as the primary determinants of the bankruptcy rate. Weiss, Bhandari, and Robins (2001) argued that variables measuring debt-paying capacity explained much of the variation in state bankruptcy rates between 1980 and 1991. Elizabeth Warren and her coauthors also focused on household debt loads and ability to pay. They argued that increased economic instability at the household level (Sullivan et al., 1989; 2000), and the pressure to purchase a home in a good neighborhood in order to obtain access to quality schools and a safe environment (Warren and Tyagi, 2003) drove the increases in bankruptcy rates in the 1980s and 1990s. That the probability of bankruptcy was lower where unemployment benefits were more generous also supported an emphasis on debt paying capacity (Fisher, 2005).

\footnotetext{
${ }^{8}$ An additional problem with the Fay, Hurst, and White (2002) study is that bankruptcy appears to be dramatically under-represented in their household survey sample. Warren and Tyagi (2003) argue that the undercount is the result of reluctance to admit to filing for bankruptcy, which itself suggests that considerable stigma still exists.
} 
Perhaps social and economic variables matter more today than in the past, while legal rules matter less. ${ }^{9}$ But perhaps the statistical insignificance of legal rules in panel studies is an artifact of the econometric technique employed. Traditional fixed effects models (Buckley and Brinig, 1998; Weiss et al., 2001) are unlikely to find a statistically significant effect of legal rules. Again, in these models, the unit-fixed effects absorb the impact of initial differences in the legal rules; the estimated coefficients on the legal rules only reflect the impact of later changes in the rules. If bankruptcy exemptions and garnishment laws changed frequently this would not present a problem. But, as described above, the legal rules seldom changed.

\section{Capturing the Effect of Legal Rules on Bankruptcy}

\section{Data and Descriptive Statistics}

To estimate the relative impact of balance sheet variables, social capital, and legal rules on bankruptcy rates we use a panel of state-level data for the years 1926-1932. The period has several features to recommend it for a study of bankruptcy rates. Again, the period precedes federal restrictions on state laws so there is ample variation in legal rules between the states. Additionally, there exists for this period an independent estimate of the severity of garnishment law that takes into consideration the difficulty of obtaining payment through garnishment, in addition to the percentage of wages exempt. Finally, the period includes the business cycle prior to the Depression, as well as the first part of the depression, which enables us to consider the impact of rapidly changing macroeconomic conditions on bankruptcy rates. ${ }^{10}$

The specific end points were determined by the availability of data. Annual state level data on divorce rates and wealth are not available for the first half of the 1920s. Meanwhile, bankruptcy

\footnotetext{
${ }^{9}$ Hynes (2006) provides evidence for Virginia and Illinois that suggests garnishment may be less relevant as a collection remedy than in the past.

10 Peaks in October 1926 and August 1929, troughs in November 1927 and March 1933.
} 
cases were not reported by occupation for 1933 through 1939 because a 1933 amendment to the Bankruptcy Act resulted in changes in the method of collecting and reporting data (U.S. Dept. of Justice, various years). Finally, while legal rules seldom change, there exists no comparable, detailed study of garnishment law that would allow the current analysis to be extended into the post-war years.

The number of bankruptcy cases filed, by occupation, is reported in the Annual Reports of the Attorney General (U.S. Dept. of Justice, various years). We use as the dependent variable the bankruptcy rate per 100,000 persons in the state. Population figures are interpolated from the census (University of Virginia, n.d.).

The macroeconomic indicators used here are the level and growth in per capita state income (Flood, 1998). A positive effect of growth would be consistent with the emphasis of Theresa Sullivan, Elizabeth Warren, and Jay Westbrook on economic uncertainty as a cause of bankruptcy (Sullivan et al., 1989).

Figure 2 shows the average bankruptcy rates in states with the highest and lowest per capita incomes. States with the highest per capita income have lower bankruptcy rates; states with the lowest per capita income have the highest bankruptcy rates.

Balance sheet indicators included here are the ratio of bank loans to aggregate state personal income (Flood ,1998) and registered vehicles per 100 persons in the state (U.S. Bureau of the Census, various years). We expect higher debt-to-income ratios to be associated with higher bankruptcy rates. The number of automobiles is likely to be a determinant of bankruptcy rates for two reasons. First, much of the consumer credit extended during the 1920s was for the purchase of automobiles (Olney, 1991), so higher rates of automobile ownership are likely to be associated with higher levels of indebtedness and bankruptcy. Second, observers during the 1920s pointed to automobile accidents—and the liability judgments stemming from them—as a significant source of 
unanticipated debt (U.S. Department of Commerce, 1931:25). Table 3 gives the average bankruptcy rate for the period in the states with the highest and lowest debt-to-income ratios and highest and lowest number of automobiles. Without controlling for other factors, we cannot find a systematic difference in bankruptcy between the states based upon the number of vehicles.

We were particularly concerned that there might be correlation between state income and debt load. Correlations are modest, however. The Pearson correlation coefficient between real state per capita income and debt-to-income ratio is 0.4 ; the correlation coefficient between real per capita income and vehicle registration is 0.3 .

Social capital variables used here are chosen for comparison to Buckley and Brinig (1998). In some specifications we include the percent of the state population that is Roman Catholic, but we focus on the percent of the state population that belongs to any religious body (U.S. Dept. of Commerce and Labor, 1930; 1940). The original sources of the data are surveys of churches conducted at ten year intervals. The annual observations are interpolated assuming a constant rate of change between surveys. If Buckley and Brinig (1998) are correct, Roman Catholic values decrease bankruptcy. If church membership provides a source of insurance, then greater membership of the population of a state in any congregation reduces bankruptcy rates.

Figure 3 shows the negative relationship between church membership and the bankruptcy rate. There is an average difference is about 10 bankruptcies per 100,000 people between states with the lowest church membership rates and states with the highest rates. The gap is larger between states with the smallest and largest Roman Catholic populations. These differences are intriguing and warrant further study, but a detailed examination is beyond the scope of the present paper.

We consider the influence of the divorce rate, measured as divorces per 1,000 persons (U.S. Bureau of the Census, various years) and the percent of state population that is urban (U.S. Bureau of the Census, various years). Degree of urbanization is expected to be positively correlated with the 
bankruptcy rate because credit may be more readily available in urban areas or because relatively anonymous urban debtors may feel less stigmatized from filing for bankruptcy. As noted above, a higher divorce rate may indicate a lack of commitment, or divorce may negatively impact the household balance sheet. In either case, a higher divorce rate is expected to increase bankruptcy. Table 3 shows, however, that before controlling for other factors, divorce and urbanicity are negatively correlated with the bankruptcy rate.

The legal rules examined here include the size of the homestead exemption relative to per capita real estate wealth (Goodman, 1993; Wickens, 1936; National Association of Credit Men, various years, U.S. Bureau of the Census, various years), personal exemption relative to per capita personal wealth (National Association of Credit Men, various years), and the severity of garnishment law in the state (Nugent et al., 1936; see below). We also include the usury rate (Ryan, 1924) and a dichotomous variable indicating whether the state had a small loan law (Nugent, 1934). The legal rules for each state are shown in Appendix A.

Homestead exemptions, in states that defined the exemption in dollar terms, varied from zero to $\$ 8,000$. Personal exemptions ranged from zero to $\$ 2,000$. The average state had an exemption-to-wealth ratio of a bit over 4 , and the variation in the ratio was large. Recall that the effect of exemptions on the bankruptcy rate is ambiguous because generous state exemptions increase the demand for loans but decrease the supply. Figure 4 shows that personal exemptions had greater impact on wage earner bankruptcy than homestead exemptions, and that the states with the highest personal property exemptions had higher bankruptcy rates. That the homestead exemption had little impact on wage earner bankruptcy is consistent with contemporary observation that the bankrupt wage earner was unlikely to own much of value for creditors to seize.

Other laws that may affect the supply of credit, indebtedness, default, and bankruptcy are state usury laws and the passage of the Uniform Small Loan Law. We include the legal maximum 
interest rate, which is the rate that a creditor was allowed to charge when the rate was not explicitly stated in a contract (Ryan, 1924; see also Nugent, 1934; Robinson and Nugent, 1935). ${ }^{11}$ The maximum legal interest rate ranged from five to eight percent. It is not clear to what extent the restrictions were actually binding (Ryan, 1924), but to the extent that usury limits were binding, they inhibited the ability of lenders to respond to increased risk by increasing interest rates. Consequently, they were likely to reduce the supply of formal credit available to wage earners and reduce the bankruptcy rate. Figure 5 shows that states with higher usury limits had higher bankruptcy rates on average.

The belief that usury laws drove low-income, high-risk borrowers to loan sharks prompted the Russell Sage foundation to draft and promote a Uniform Small Loan Law beginning in 1913 (Robinson and Nugent, 1935). The small loan law offered an exception to the usury law. Lenders who complied with the regulations set forth in the law were allowed to charge higher interest rates for loans under $\$ 600$. About half of all states passed a version of the uniform small loan law by 1933 (Nugent, 1934). Figure 6 shows that states without a small loan law had slightly higher rates than states with special provisions for small loans.

The severity of state garnishment law was assessed by Nugent, Hamm, and Jones (1936) as part of a broad study of consumer credit conditions that commenced in 1934. They considered many aspects of garnishment law, from the fraction of wages that were exempt to the difficulty of actually receiving a payoff through garnishment. The study categorized state garnishment laws as being severe, limited, or lenient from the perspective of the debtor. Severe laws were ones that did not appear to leave enough for the support of a wage earner's family; limited laws left an adequate amount for support of a family; ineffective laws were ones in which wages were generally not subject to garnishment. The Nugent, Hamm and Jones study covered 23 states; we classified an additional

\footnotetext{
11 Wyoming was the only state to change its usury rate during the 1920 s.
} 
seven states through comparison with other sources (Sturges and Cooper, 1933; Douglas, 1933;

National Association of Credit Men, various years). We compare states with severe (pro-creditor) and lenient (pro-debtor) garnishment law to states with garnishment laws that these scholars reported had limited impact. On the face of it, the severity of garnishment law appears to explain much of the difference in the bankruptcy rates between the states. States with severe laws had some of the highest bankruptcy rates while many states with lenient laws had very low rates. Figure 7 shows the bankruptcy rate in states with severe garnishment rules and lenient garnishment laws. On average, states with severe garnishment had bankruptcy rates nine times larger than states with lenient garnishment law.

We considered whether legal rules were co-determined; that is, we thought states might have consistently pro-debtor or pro-creditor rules. Examination of Appendix A, though, makes it clear that states did not have coordinated legal rules. Only Colorado took a strictly pro-creditor stance: no small loan law, the highest usury limit, low personal exemptions, and severe garnishment law. Louisiana was the only state with a strictly pro-debtor stance: a small loan law, a usury limit of five percent, personal exemptions over $\$ 2,000$, and limited garnishment.

Consider now the pooled cross-sectional time-series regression model

$$
r_{s t}=\alpha+X_{s t} \beta+L_{s t} \gamma+\varepsilon_{s t},
$$

where $r_{s t}$ is the wage earner bankruptcy rate in each state $s$ and year $t$. The vector $X_{s t}$ includes macroeconomic indicators, balance sheet indicators, and social capital indicators that vary over time in each state and have been found to influence the bankruptcy rate. The vector $L_{s t}$ includes legal variables, such as the exemptions in bankruptcy and the severity of garnishment law. ${ }^{12}$

\footnotetext{
12 Because the bankruptcy rate can be thought of as the number of filings out of the population of people who might file, we also considered a binomial regression specification. The binomial specification did not fit the data well and are not presented here.
} 
Table 4 shows the results of the model in (1). The number of observations is limited mainly by the availability of the data on legal rules. Of a possible 357 observations, 140 are lost because 20 states are not included in the independent rating of severity of garnishment law; additional states are lost because the way personal exemptions are described in state laws make them non-comparable. We found, however, no statistically significant difference between states included in the regression and those excluded.

The first columns of table 4 show the regressions with the wage earner bankruptcy rate as the dependent variable. Because of leftward skew in the distribution of wage earner bankruptcy rates, we also consider the semi-log specification; the results are shown in the final columns of table 4. After correcting for within-state heteroskedasticity, the residuals are approximately normally distributed in all specifications. The regression results are consistent with the descriptive statistics discussed above. The level of per capita income is modestly and negatively associated with the bankruptcy rate, but growth is not. The balance sheet variables have little measurable impact. Of the social capital variables, church membership is the most important, and it is the only one that is statistically significant in all specifications.

Legal rules, especially garnishment law, drive the bankruptcy rate. Doubling income from the average of $\$ 443$ would be expected to decrease the bankruptcy rate by 13 , but switching from an ineffective to lenient garnishment law is expected to decrease the bankruptcy rate by 19 bankruptcies per 100,000 persons.

The pooled cross-section time series approach may be warranted if concern over omitted variables bias is minimal. Given that the models presented in table 4 explain a majority of the variation in the bankruptcy rate, it may be tempting to consider the case solved. However, we are unable to capture the effects of many economic, social, and legal variables that could influence bankruptcy. These include, but are not limited to, industrial structure, immigration, and, especially, 
the operation of the district bankruptcy courts themselves. Relying on pooled OLS does not offer a way to reduce the bias from these omitted variables. Of course, it is well known that excluding an independent variable that is correlated with the dependent variable creates bias unless the excluded variable and the included variables are orthogonal to each other. It is the same for fixed effects that are excluded despite correlation with the dependent variable. It seems, therefore, unlikely that our results in table 4 are unbiased, especially for such a small number of observations.

We allow for state fixed effects to capture the state-specific variation in these omitted variables. The fixed effects model is

$$
r_{s t}=\alpha+X_{s t} \beta+u_{s}+\varepsilon_{s t}
$$

where $r_{s t}$ is the wage earner bankruptcy rate in each state $s$ and year $t$. The vector $X_{s t}$ includes macroeconomic indicators, balance sheet indicators, and social capital indicators that vary over time in each state and have been found to influence the bankruptcy rate. The results of the fixed effects specification appears in the first column of table 5.

In the fixed effects specification, of the economic, balance sheet, and social capital variables, only the church membership and divorce have detectable effects. The ratio of personal exemptions, which is driven by changes in the value of wealth over the period, has a positive impact on the bankruptcy rate.

The vector of state-specific but time-invariant legal variables, such as the severity of garnishment law, are perfectly colinear with the state-specific fixed effect $u_{s}$ and cannot be estimated in the basic fixed effects framework. In this case, random effects may serve as a viable second best option, even if the Hausman test suggested that random effects are inconsistent (Pluemper and Troeger, forthcoming). The random effects results are shown in the second column of table 5 .

Random effects estimation yields signs that are consistent with the signs of the coefficients in the pooled OLS specification, but random effects is unable to find any clear relationships in the 
data, except for a weakly significant and negative relationship between the homestead exemptions and the bankruptcy rate. Recall, however, that random effects (1) requires strict exogeneity and orthogonality between included independent variables and the random effect, and that (2) random effects models share the poor small sample properties of all generalized least squares techniques. As a consequence, we are skeptical of the random effects estimates.

Hausman and Taylor (1981) suggest using instruments for the variables that are likely to be correlated with the random effects. The Hausman-Taylor results, assuming exogenity of the legal rules, are presented in the final column of table 5. Again, the standard errors of the estimates are large. However, most signs (but not) are again consistent with the pooled OLS results. Finally, like most instrumental variables techniques, the results of the Hausman-Taylor procedure are highly sensitive to our choices about which variables are endogenous and which variables.

\section{An Augmented Fixed-Effects Procedure}

Fixed effect vector decomposition is a new procedure that allows us to retain the desirable features of the fixed effects framework without losing information about the time-invariant legal rules in the process (Pluemper and Troeger, forthcoming). The model is

$$
r_{s t}=\alpha+X_{s t} \beta+L_{s} \gamma+u_{s}+\varepsilon_{s t}
$$

where $r_{s t}$ is the wage earner bankruptcy rate in each state $s$ and year $t$. The vector $X_{s t}$ includes macroeconomic indicators, balance sheet indicators, and social capital indicators that vary over time in each state. The vector $L_{s}$ includes state-specific but time-invariant (or nearly time-invariant) legal variables, such as the exemptions in bankruptcy and the severity of garnishment law. The statespecific fixed effect $u_{s}$ is assumed to be correlated with at least one of the variables in $X$ and one of the variables in $L$. 
Fixed effect vector decomposition is a three-stage estimation procedure. The first stage estimates the usual fixed effects model, as in the first column of table 5. The within-estimator identifies the state effect as the part of the mean of the state bankruptcy rate that cannot be explained by the time-varying variables:

$$
\hat{u}_{s}=\bar{r}_{s}-\bar{x}_{s} \hat{\beta}
$$

The second stage of the procedure estimates by OLS the effect of the time-invariant elements of $L$ on the fixed effects,

$$
\hat{u}_{s}=\phi+l_{s} \gamma+v_{s}
$$

where $\phi$ is a constant term and $v_{s}$ is an error term. In the third stage, after adjusting the degrees of freedom, the results from the second stage estimation are included in a pooled OLS re-estimation of the model, so that

$$
r_{s t}=\alpha+x_{s t} \beta+l_{s} \gamma+v_{s}+\varepsilon_{s t}
$$

The inclusion of $v_{s}$ in the final stage accounts for the part of the original state effect that is due to still-omitted variables. The coefficient on $v_{s}$ is expected to equal one after correction for heteroscedasticty or serial correlation. Pluemper and Troeger (forthcoming) show that this procedure has nicer finite sample properties than alternatives already discussed for estimating the effect of time-invariant variables using panel data.

Table 6 shows the results of the fixed effect vector decomposition procedure. By accounting for both time-varying and time-invariant explanatory variables using fixed effect vector decomposition, we are able to explain 90 percent of the variation in bankruptcy rates (table 3$).{ }^{13}$ In specification (1) of table 6 the levels of the homestead and personal exemptions are treated as (nearly) time-invariant. They are not included in the fixed effect specification of the first stage, but

${ }^{13}$ Such a high $\mathrm{R}^{2}$ led us to suspect serial correlation of course, but the Durbin-Watson test was inconclusive. Results with an $\mathrm{AR}(1)$ correction are not substantively different from those presented in table 3 . 
the effects of the exemptions are instead decomposed from the state fixed effect in the second stage (equation (5) above) and included in the pooled estimation of the third stage (equation (6)). The level of personal exemptions has a positive and statistically significant effect on the bankruptcy rate, but after controlling for state macroeconomic conditions, the level of the homestead exemption is negatively correlated with the bankruptcy rate. ${ }^{14}$

In specifications (2) through (4) the homestead and personal exemptions are considered relative to per capital real estate and personal wealth in the state. The ratio of exemptions to wealth more directly measures the generosity of bankruptcy law because average wealth varies greatly across states. Changes in the value of assets during this period generated substantial variation within states across time. The higher the ratio of the homestead exemption to average real estate wealth, the lower the bankruptcy rate, and the effect is again statistically significant.

As discussed above, the representative wage earner was more likely to be concerned with the personal exemption. As the personal exemption relative to average wealth increased, so did the bankruptcy rate. The effect of this ratio is positive and statistically significant in each specification. Specification (3) differs from specifications (1) and (2) in its measurement of the social capital indicator for religion. Recall that Buckley and Brinig (1998) suggested that a Roman Catholic population would value fulfilling commitments and would therefore have a lower bankruptcy rate. Other studies suggested that church membership, regardless of the specific congregation, would provide insurance against negative income shocks. Specifications (1) and (2) include the general measure of church membership. Greater church membership is associated with lower bankruptcy rates, and the effect is statistically significant. A larger Roman Catholic population (specification 3) is also associated with a lower bankruptcy rate, but the effect is smaller. Thus the data for 19261932 lend some evidence that membership in any religious congregation, rather than a specific one,

\footnotetext{
14 The residuals are approximately normal. Semi-log and $\log -\log$ specifications return similar results.
} 
provided benefits in times of distress. Again, we defer further consideration of this phenomenon to another paper.

In specifications (2) and (3) there is a small, but statistically significant, association between the level of real per capita income and the bankruptcy rate, indicating that the supply of credit to wage earners was likely greater in richer states. The annual growth in state real per capita income is not statistically associated with the bankruptcy rate. Specification (4) shows that the insignificance of macroeconomic fluctuations is not an artifact of non-linearity in the relationship between growth and bankruptcy. The coefficients on the squares of income and growth are not statistically different from zero.

In all four specifications shown in table 6 , the two balance sheet indicators-the ratio of total bank loans to aggregate state personal income and the number of registered vehicles per 100 persons in the state — are consistently and positively associated with the bankruptcy rate. That is, greater indebtedness led to greater risk of bankruptcy.

The divorce rate, too, is consistently and positively associated with the bankruptcy rate. This may be due to the negative impact of divorce on the household balance sheet, or it may indicate a more casual attitude towards fulfilling commitments. Similarly, the effect of urbanization on bankruptcy rates is consistently positive. It may be that stigma is less in urban areas, or it may be that loans are more readily available there.

Of the state legal rules included, the effect that is least robust to specification is the effect of the existence of a small loan law. States with small loan laws have lower bankruptcy rates in each of the specifications. However, in specification (2) the effect of the small loan law is not statistically 
significant. Moreover, the estimated coefficients range widely, with the 95 percent confidence intervals encompassing the range from -34 to $-4 .^{15}$

In contrast, higher usury limits are consistently associated with higher bankruptcy rates. The effect of the usury limit is quite large. A step-up in the usury limit of one percentage point is associated with an increase in the bankruptcy rate of between 8 and 18 filings per 100,000 people; compare this to the average rate of 22.2 per 100,000 or the median rate of 14.6 per 100,000 . A move from the lowest to the highest usury limit (from 5 to 8 percent) could thus move a state from the bottom to the top quartile in terms of its bankruptcy rate.

The severity of garnishment law explains much of the difference between state bankruptcy rates. The bankruptcy rate in a state with a severe garnishment law is predicted to be higher than the rate in an otherwise identical state with lenient law by between 29 and 37 filings per 100,000 persons in the state. (Compare the coefficients on severe and lenient garnishment in specifications (1) and (2).) As is the case with legal limits on interest, a switch in legal rules from lenient garnishment to severe garnishment could move a state from the $25^{\text {th }}$ percentile to the top quartile in terms of the bankruptcy rate. Or consider it this way: if all states had adopted lenient garnishment rules before 1926, we would expect the average state bankruptcy rate for the period to have been 13.5 rather than 22.2.

Taken together, the results in table 6 tell a persuasive story about the importance of legal rules in determining bankruptcy rates. Differences in the legal rules governing how easily a creditor could collect from a wage earner in default explain most of the variation in bankruptcy rates between states from 1926 through 1932. Alternations in state-specific legal rules, especially rules

\footnotetext{
15 Terms interacting the effect of the small loan law and the other legal variables were not statistically significant. We also considered the possibility that state laws were correlated, that is, we considered whether states could be categorized as pro-debtor or pro-creditor by looking at their policies as whole. They cannot. The correlation coefficient between homestead and personal exemptions is 0.43 ; the correlation between the usury rate and personal exemptions is 0.33 . States with a lenient garnishment law have higher ratios of homestead exemptions to real estate wealth $(p$-value $<.05)$, but do not have different ratios of personal exemptions to personal wealth.
} 
affecting the supply of credit and creditors' remedies, would have entirely changed the picture of bankruptcy in the United States. Changes in social capital and balance sheet indicators also influenced bankruptcy rates, but it would have required relatively large changes in these variables to have changed the national picture of bankruptcy.

\section{Conclusion}

A comparison of our results with studies using more recent data suggests avenues for further research. The most striking difference, of course, is that using fixed effect vector decomposition we consistently find a strong relationship between garnishment law and bankruptcy rates for 1926-1932, whereas some studies using recent data are unable to identify such a relationship. A fresh look at the data for the 1980s and 1990s using fixed effect vector decomposition will tell us whether the divergence in results is caused by a decline in the importance of garnishment laws or by the differences in econometric techniques.

Our results also provide support for an argument made by David Skeel (1998). In his study of corporate reorganization, Skeel found that bankruptcy law cannot be understood in isolation from other laws, but must be examined in the context of the regulatory environment. Our work shows that in the case of wage earner bankruptcy, bankruptcy law must be examined in the context of state garnishment laws, exemption laws, and usury laws. The same federal bankruptcy law can produce dramatically different outcomes in different states depending on the legal context.

Finally, although differences in legal rules are the most important factor in determining differences in bankruptcy rates from 1926-32, the impact of the social variables, particularly church membership, is also robust. The mechanisms by which these social capital variables influence bankruptcy rates require further exploration. 


\section{$\underline{\text { References }}$}

Argarwal, Sumit, Souphala Chomsisengphen, Chunlin Liu, LawranceMielnicki (2005). "Impact of State Exemption Laws on Small Business Bankruptcy Decision.” Southern Economic Journal 71(3): 620-635

Agarwal, Sumit, Chunlin Liu, and Lawrence Mielnicki (2003). "Exemption Laws and Consumer Delinquency and Bankruptcy Behavior: An Empirical Analysis of Credit Card Data." The Quarterly Review of Economics and Finance 43: 272-89.

Amemiya, T., and T. MaCurdy (1986). "Instrumental-variable Estimation of an Error-Components model." Econometrica 54(4): 869-880.

Apilado, Vincent, Joel J. Dauten, and Douglas E. Smith (1978). “Personal Bankruptcies.” Journal of Legal Studies 7: 371-392.

Balleisen, Edward (2001). Navigating Failure: Bankruptcy and Commercial Society in Antebellum America. University of North Carolina Press: Chapel Hill.

Berkowitz, Jeremy, and Richard Hynes (1999). "Bankruptcy Exemptions and the Market for Mortgage Loans." Journal of Law and Economics 42: 908-830.

Berkowitz, Jeremy, and Michelle White (2004). "Bankruptcy and Small Firms' Access to Credit." RAND Journal of Economics 35: 69-84.

Boyes, William, and Roger Faith (1986). "Some Effects of the Bankruptcy Reform Act of 1978." Journal of Law and Economics 19:139-49.

Buckley, Frank, and Margaret Brinig (1998). “The Bankruptcy Puzzle.” Journal of Legal Studies 27: 187-208.

Carruthers, Bruce, and Terrence Halliday (1998). Rescuing Business: The Making of Corporate Bankruptcy Law in England and the United States. Oxford University Press. 
Dawsey, Amanda E., and Ausubel, Lawrence M. (2002). "Informal Bankruptcy." Twelfth Annual Utah Winter Finance Conference. ONLINE. Available: http://ssrn.com/abstract=332161

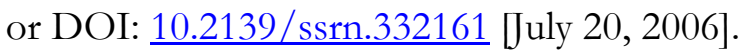

Dehejia, Rajeev, Thomas DeLeire, and Erzo F.P. Luttmer (2005). "Insuring Consumption and Happiness Through Religious Organizations.” NBER Working Paper 11576. ONLINE. Available: http://www.nber.org/papers/w11576 [July 23, 2006].

Domowitz, Ian, and Thomas Eovaldi (1993). “The Impact of the Bankruptcy Reform Act of 1978 on Consumer Bankruptcy." Journal of Law and Economics 36: 803-835.

Douglas, William O. (1933). “Wage Earner Bankruptcies—State vs. Federal Control.” Yale Law Journal 42: 591-642.

Fay, Scott, Erik Hurst, and Michelle J. White (2002). “The Household Bankruptcy Decision.” American Economic Review 92 (3): 706-18.

Fisher, Jonathan D. (2005). "The Effect of Unemployment Benefits, Welfare Benefits, and Other Income On Personal Bankruptcy." Contemporary Economic Policy 23: 483-492.

Flood, Mark D. (1998). United States Historical Data on Bank Market Structure, 1896-1955 [Computer file]. ICPSR version. Montreal, Quebec: Mark D. Flood, Concordia University [producer]. Ann Arbor, MI: Inter-university Consortium for Political and Social Research [distributor].

Goodman, Paul (1993). “The Emergence of Homestead Exemption in the United States: Accomodation and Resistance to the Market Revoluation, 1840-1880." The Journal of American History 80(2): 470-498.

Gropp, Reint, John Scholz, and Michelle White (1997). "Personal Bankruptcy and Credit Supply and Demand." The Quarterly Journal of Economics 112: 217-51. 
Gross, David, and Nicholas Souleles (2002). “An Empirical Analysis of Personal Bankruptcy and Delinquency." The Review of Financial Studies 15 (1): 319-347.

Hansen, Bradley (1998). "Commercial Associations and the Creation of a National Economy: The Demand for a Federal Bankruptcy Act.” Business History Review, 72: 84-113.

---- (2000). “The People’s Welfare and the Origins of Corporate Reorganization: The Wabash Receivership Reconsidered.” Business History Review 74: 377-405.

---- , and Mary Eschelbach Hansen (forthcoming). "Path Dependence in the Development of U.S. Bankruptcy Law, 1880-1938.” Journal of Institutional Economics.

Hausman, Jerry A., and William E. Taylor (1981). "Panel Data and Unobservable Individual Effects." Econometrica 49: 1377-1398.

Heck, Ramona (1981). “An Econometric Analysis of Interstate differences in Nonbusiness Bankruptcy and Chapter 13 Rates.” Journal of Consumer Affairs 15: 13-31.

Holmes, Jjessica, Jonathan Isham, Jessica Wasilweski (2005). “Overcoming Information Asymetries in Low-Income Lending: Lessons from the 'Working Wheels’ Program.” Southern Economic Journal 72(2): 329-351.

Hynes, Richard M. (2006). "Bankruptcy and State Collections: The Case of Missing Garnishments." Cornell Law Review 91: 603-652.

-----, Anup Milani, and Eric Posner (2004). “The Political Economy of Property Exemption Laws." Journal of Law and Economics 47: 19-43.

Lin, E. Y., and Michelle White (2001). "Bankruptcy and the Market for Mortgage and Home Improvement Loans." Journal of Urban Economics 50: 138-162.

Lyons, Angela C., and Tansel Yilmazer (2005). "Health and Financial Strain: Evidence from the Survey of Consumer Finances.” Southern Economic Journal 71(4): 873-890. 
Mann, Bruce H. (2003). Republic of Debtors: Bankruptcy in the Age of American Independence. Harvard University Press: Cambridge.

Moss, David A., and Gibbs A. Johnson. (1999). "The Rise of Consumer Bankruptcy: Evolution, Revolution, or Both?” American Bankruptcy Law Journal 73: 311-51.

National Association of Credit Men (1930, 1935, 1938). Credit Manual of Commercial Laws. National Association of Credit Men: New York.

Nelson, Jon P. (1999). “Consumer Bankruptcy and Chapter Choice: State Panel Evidence.” Contemporary Economic Policy 17: 552-567.

Nugent, Rolf (1934). "Small Loan Debt in the United States." The Journal of Business of the University of Chicago VII (1): 1-21.

-----, John E. Hamm, and Frances Jones (1936). 'Wage Executions for Debt.” Bureau of Labor Statistics Bulletin No. 622. Washington: GPO.

Nunez, Steven, and Howard Rosenthal (2004). "Bankruptcy Reform in Congress: Creditors, Committees, Ideology, and Floor Voting in the Legislative Process." Journal of Law, Economics and Organization 20: 527-557.

Olney, Martha (1991). Buy Now, Pay Later: Advertising, Credit, and Consumer Durables in the 1920s. University of North Carolina Press: Chapel Hill.

Pluemper, Thomas, and Vera E. Troeger, Vera E. (forthcoming). "The Estimation of TimeInvariant Variables in Panel Analyses with Unit Fixed Effects." Political Analysis. ONLINE. Available: http://ssrn.com/abstract=565904 [July 1, 2006].

Robinson, Louis N., and Rolf Nugent. (1935). Regulation of the Small Loan Business. Russell Sage: New York.

Ryan, Franklin W. (1924) Usury and Usury Laws. Houghton Mifflin: Boston. 
Sandage, Scott (2005). Born Losers: A History of Failure in America. Harvard University Press:

Cambridge.

Shepard, Lawrence (1984). "Personal Failures and the Bankruptcy Act of 1978." Journal of Law and

Economics 27: 419-37.

Shiers, Alden, and Daniel Williamson (1987). "Nonbusiness Bankruptcy and the Law: Some Empirical Results.” The Journal of Consumer Affairs 21: 277- 292.

Skeel, David (2001). Debt's Dominion: A History of Bankruptcy Law in America. Princeton: Princeton University Press.

----- (1998). “An Evolutionary Theory of Corporate law and Corporate Bankruptcy.” Vanderbilt Law Review 51:1325-1398.

Stanley, David T., and Marjorie Girth (1971). Bankruptcy: Problem, Process and Reform. Brookings Institution: Washington.

Sturges, Wesley, and Don E. Cooper (1933). “Credit Administration and Wage Earner Bankruptcies." Yale Law Journal 42: 487-525.

Sullivan, Teresa, Elizabeth Warren, and Jay Westbrook (1989). As We Forgive Our Debtors: Bankruptcy and Consumer Credit in America. Oxford University Press, New York.

-----, (2000). The Fragile Middle Class. Yale University Press: New Haven.

Tabb, Charles Jordan (1991). “The Historical Evolution of Bankruptcy Discharge.” American Bankruptcy Law Journal 65: 325-71.

U.S. Bureau of the Census (various years). Statistical Abstract of the United States. GPO: Washington, DC. ONLINE. Available: http://www.census.gov/compendia/statab/past years.html [June 23, 2006]. 
U.S. Department of Commerce and Labor, Bureau of the Census (1930). Census of Religious Bodies 1926, Part I: Summary and Detailed Tables. GPO: Washington, D.C. ONLINE. Available: http://216.122.145.46/arda.asp?Show=Home [June 23, 2006].

U.S. Department of Commerce and Labor, Bureau of the Census (1940). Census of Religious Bodies 1936, Part I: Summary and Detailed Tables. GPO: Washington, D.C. ONLINE. Available: http://216.122.145.46/arda.asp?Show=Home [June 23, 2006].

U.S. Department of Commerce, Bureau of Foreign and Domestic Commerce (1931). "Causes of Business Failures and Bankruptcies of Individuals in New Jersey in 1929-30.” Domestic Commerce Series No. 54. GPO: Washington D.C.

U.S. Department of Justice, (various years). Annual Report of the Attorney General of the United States. Washington, DC: GPO.

University of Virginia Geospatial and Statistical Data Center (n.d.). "United States Historical Census Data Browser.” ONLINE. University of Virginia. Available: http:// fisher.lib.virginia.edu/census/. [August 2004].

Warren, Charles (1935). Bankruptcy In United States History. Harvard University Press: Cambridge. Warren, Elizabeth, and Amelia Warren Tyagi (2003). The Two Income Trap. Basic Books: New York. Weiss, Lawrence, Jagdeep Bhandari, and Russell Robins (2001). “An Analysis of State Variation in Bankruptcy Rates In the United States.” Bankruptcy Developments Journal 17: 408- 424.

White, Michelle (1987). “Personal Bankruptcy under the 1978 Bankruptcy Code: An Economic Analysis." Indiana Law Journal 63:1-53.

---- . (1998). “Why Don't More Households File For Bankruptcy?” Journal of Law, Economics and Organization 14:208-231. 
-----. (2006). "Bankruptcy and Consumer Behavior: Theory and Evidence from the United States." In Giuseppe Bertola, Richard Disney, and Charles Grant. The Economics of Consumer Credit. MIT Press.

Wickens, David L. (1936). “Farmer Bankruptcies, 1898-1935.” United States Department of Agriculture Circular No. 414. GPO: Washington, D.C. 
Appendix A. Legal Rules

\begin{tabular}{|c|c|c|c|c|}
\hline $\begin{array}{r}\text { Homestead } \\
\text { Exemption } \\
(\$)\end{array}$ & $\begin{array}{r}\text { Personal } \\
\text { Exemption } \\
(\$)\end{array}$ & $\begin{array}{r}\text { Garnishment } \\
\text { Law }\end{array}$ & $\begin{array}{r}\text { Maximum } \\
\text { Legal } \\
\text { Interest } \\
\text { Rate }(\%)\end{array}$ & $\begin{array}{l}\text { Small } \\
\text { Loan } \\
\text { Law? }\end{array}$ \\
\hline 2000 & 1000 & Severe & 8 & $\mathrm{No}$ \\
\hline 2500 & 700 & Ineffective & 6 & $\mathrm{No}$ \\
\hline 4000 & $\mathrm{n} / \mathrm{a}$ & Not Ranked & 6 & Yes \\
\hline 5000 & $B$ & Ineffective & 7 & \\
\hline 2000 & 200 & Severe & 8 & $\mathrm{No}$ \\
\hline 1000 & $B$ & Not Ranked & 6 & Yes \\
\hline 0 & 700 & Not Ranked & 6 & No \\
\hline 0 & 250 & Not Ranked & 6 & $\mathrm{No}$ \\
\hline$A$ & 1000 & Ineffective & 8 & Yes \\
\hline 1600 & 1600 & Severe & 7 & Yes \\
\hline$A$ & $B$ & Not Ranked & 6 & Yes \\
\hline 5000 & 1300 & Not Ranked & 7 & No \\
\hline 1000 & 400 & Severe & 5 & Yes \\
\hline 600 & 1200 & Ineffective & 6 & Yes \\
\hline$A$ & $B$ & Severe & 6 & $\mathrm{No}$ \\
\hline 1000 & $B$ & Severe & 6 & $\mathrm{No}$ \\
\hline 2000 & B & Limited & 5 & 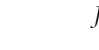 \\
\hline 800 & 100 & Limited & 6 & Yes \\
\hline 0 & 100 & Ineffective & 6 & Yes \\
\hline 500 & B & Severe & 6 & Yes \\
\hline 1500 & C & Severe & 5 & Yes \\
\hline A & 0 & Severe & 6 & No \\
\hline 1500 & 400 & Limited & 6 & $K$ \\
\hline 3000 & 250 & Not Ranked & 6 & $\mathrm{No}$ \\
\hline 2500 & $B$ & Not Ranked & 8 & No \\
\hline 1000 & 500 & Ineffective & 6 & No \\
\hline 8000 & $D$ & Ineffective & 6 & $\mathrm{No}$ \\
\hline 2000 & 500 & Not Ranked & 7 & $\mathrm{No}$ \\
\hline 500 & 200 & Not Ranked & 6 & Yes \\
\hline 1000 & 200 & Limited & 6 & Yes \\
\hline 1000 & 500 & Not Ranked & 6 & No \\
\hline 5000 & $F$ & Ineffective & 7 & $\mathrm{No}$ \\
\hline 1000 & 250 & Limited & 6 & Yes \\
\hline 1000 & $F$ & Limited & 6 & Yes \\
\hline 5000 & $B$ & Not Ranked & 6 & No \\
\hline 3000 & 275 & Severe & 6 & Yes \\
\hline 0 & 300 & Ineffective & 6 & Yes \\
\hline 0 & $B$ & Not Ranked & 6 & Yes \\
\hline 1000 & G & Ineffective & 7 & $\mathrm{No}$ \\
\hline 5000 & 750 & Not Ranked & 7 & No \\
\hline 1000 & $B$ & Severe & 6 & Yes \\
\hline 5000 & B & Ineffective & 6 & $\mathrm{No}$ \\
\hline
\end{tabular}




$\begin{array}{lrrrrr}\text { UT } & 2000 & B & \text { Not Ranked } & 8 & \text { Yes } \\ \text { VA } & 2000 & 2000 & \text { Severe } & 6 & \text { Yes } \\ \text { VT } & 1000 & H & \text { Not Ranked } & 6 & \text { No } \\ \text { WA } & A & 500 & \text { Ineffective } & 6 & \text { No } \\ \text { WI } & 5000 & 400 & \text { Not Ranked } & 6 & K \\ \text { WV } & 1000 & 200 & \text { Not Ranked } & 6 & \text { Yes } \\ \text { WY } & 2500 & 1250 & \text { Not Ranked } & 8 & 0\end{array}$

Sources: See text.

Notes:

${ }^{A}$ Homestead exemption defined in acres.

${ }^{B}$ Personal exemption itemized.

${ }^{C}$ Decreased from 850 to 500 in 1932.

${ }^{D}$ Increased from 1000 to 1500 in 1932.

${ }^{E}$ Increased from 2200 to 3200 in 1932.

${ }^{F}$ Increased from 250 to 1000 in 1932.

${ }^{G}$ Decreased from 800 to 500 in 1932.

${ }^{H}$ Established dollar amount equal to 400 in 1932.

${ }^{I}$ Passed in 1931.

${ }^{J}$ Passed in 1932.

${ }^{K}$ Passed in 1927. 
Table 1. Homestead Exemptions in 1883, 1920 and 1932 (in dollars)

\begin{tabular}{lrrr} 
& \multicolumn{3}{c}{ Year } \\
& $\underline{1883}$ & $\underline{1920}$ & $\underline{1932}$ \\
AL & 2000 & 2000 & 2000 \\
AR & 2500 & 2500 & 2500 \\
AZ & 5000 & 4000 & 4000 \\
CA & 5000 & 5000 & 5000 \\
CT & n.a. & 1000 & 1000 \\
GA & 1600 & 1600 & 1600 \\
ID & 500 & 5000 & 5000 \\
IL & 1000 & 1000 & 1000 \\
IN & 600 & 600 & 600 \\
KY & 1000 & 1000 & 1000 \\
LA & 2000 & 2000 & 2000 \\
MA & 800 & 800 & 800 \\
ME & 500 & 500 & 500 \\
MO & 1500 & 1500 & 1500 \\
MS & 2000 & 3000 & 3000 \\
NC & 1000 & 1000 & 1000 \\
NE & 2000 & 2000 & 2000 \\
NH & 500 & 500 & 500 \\
NJ & 1000 & 1000 & 1000 \\
NM & 1000 & 1000 & 1000 \\
NV & 5000 & 5000 & 5000 \\
NY & 1000 & 1000 & 1000 \\
OH & 1000 & 1000 & 1000 \\
OK & 5000 & 5000 & 5000 \\
PA & 300 & 300 & 300 \\
SC & 1000 & 1000 & 1000 \\
TN & 1000 & 1000 & 1000 \\
TX & 5000 & 5000 & 5000 \\
UT & 1000 & 1500 & 2000 \\
VA & 2000 & 2000 & 2000 \\
VT & 500 & 500 & 1000 \\
WV & 1000 & 1000 & 1000 \\
WY & 1000 & 2500 & 2500
\end{tabular}

Sources: See text. 
Table 2. Descriptive Statistics (All States)

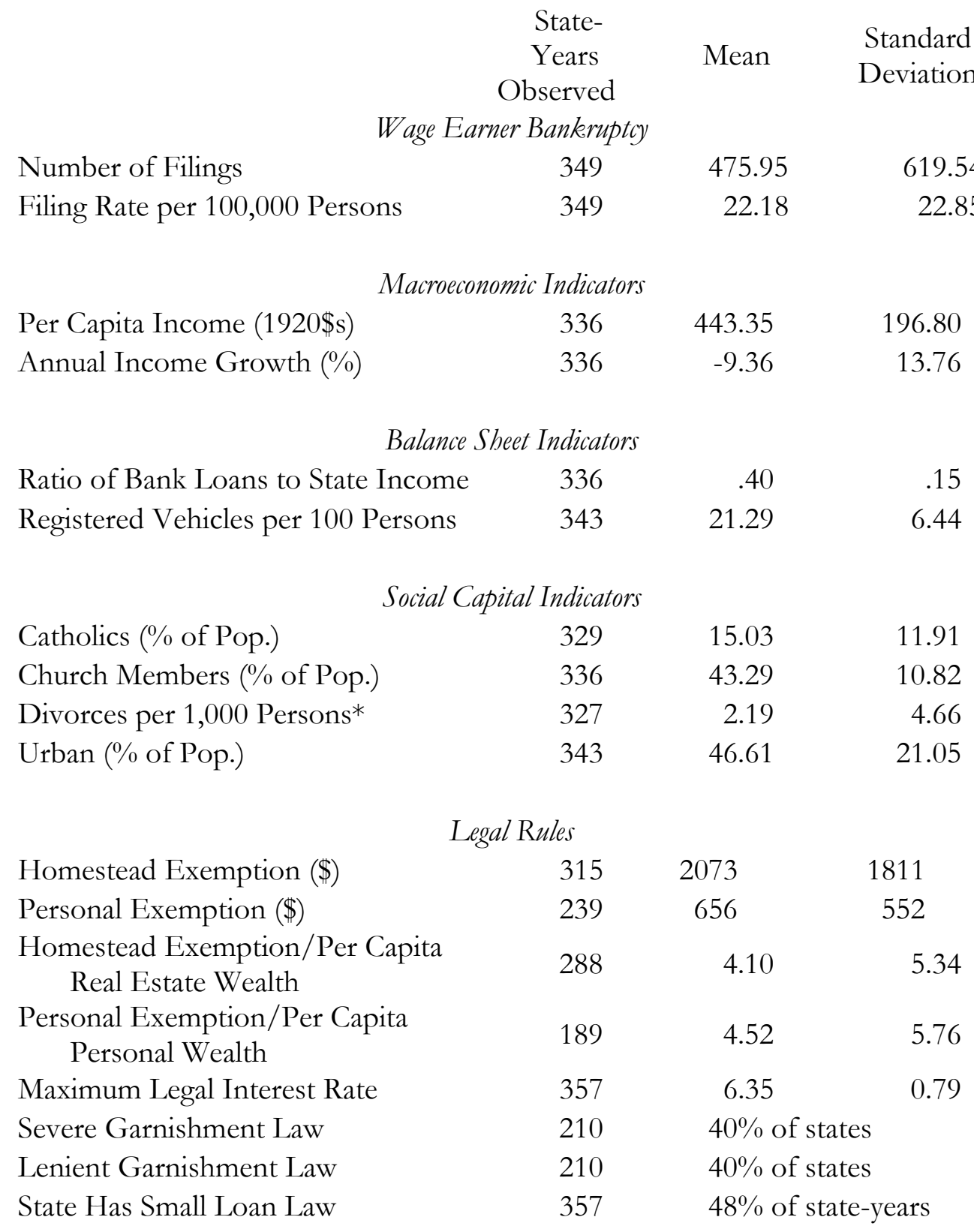

Sources: See text.

* May also be interpreted as a balance sheet indicator; see text. 
Table 3. Balance Sheet Indicators, Social Capital Variables, and Bankruptcy Rates

\begin{tabular}{lcc} 
& \multicolumn{2}{c}{ Bankruptcy Rate in } \\
& Lowest Quartile & Highest Quartile \\
& of States & of States \\
Ratio of Bank Loans to State Income & 24.7 & 24.0 \\
& $(29.6)$ & $(20.5)$ \\
Registered Vehicles per 100 Persons & 29.5 & 21.8 \\
Divorces per 1,000 Persons & $(32.2)$ & $(17.9)$ \\
Percent of State Population in Urban Areas & 15.4 & 9.7 \\
& $(18.8)$ & $(9.9)$ \\
& $(21.3$ & $(9.97)$
\end{tabular}

Source: See text.

Standard deviations in parentheses. 
Table 4. Pooled Cross-Section Time-Series Results

Dependent Variable

Real Per Capita Income

Income Growth

Loan to Income Ratio

Registered Vehicles per 100 Persons

Church Members (\% of Pop.)

Divorces per 1,000 Persons

Urban (\% of Pop.)

Homestead Exemption/Per Capita Real Estate Wealth

Personal Exemption/Per Capita Personal Wealth

Maximum Interest Rate

State Has Small Loan Law

Severe Garnishment Law

Lenient Garnishment Law

Year Effects?

$\mathrm{N}$

$\mathrm{R}^{2}$

\begin{tabular}{cc}
\multicolumn{2}{c}{ Bankruptcies } \\
\hline 100 KPop \\
-0.03 & $-0.08^{* *}$ \\
$(0.03)$ & $(0.02)$ \\
16.78 & 18.14 \\
$(32.25)$ & $(30.77)$ \\
0.01 & 0.01 \\
$(0.02)$ & $(0.01)$ \\
-0.38 & -0.52 \\
$(0.39)$ & $(0.35)$ \\
$-0.70^{* *}$ & $-0.75^{* *}$ \\
$(0.39)$ & $(0.23)$ \\
$-0.57 *$ & $-0.55^{*}$ \\
$(0.30)$ & $(0.30)$ \\
0.09 & $0.55^{* *}$ \\
$(0.23)$ & $(0.22)$ \\
$-1.06^{* *}$ & $-1.45^{* *}$ \\
$(0.42)$ & $(0.35)$ \\
$1.17^{* *}$ & $0.96^{* *}$ \\
$(0.60)$ & $(0.38)$ \\
$5.03^{*}$ & $7.06^{* *}$ \\
$(2.92)$ & $(2.58)$ \\
-3.17 & -3.81 \\
$(5.04)$ & $(4.76)$ \\
$15.58^{* *}$ & \\
$(5.79)$ & \\
$-19.31^{* *}$ & \\
$(3.24)$ & \\
Yes & Yes \\
133 & 187 \\
0.56 & 0.22 \\
&
\end{tabular}

$\ln \left(\frac{\text { Bankruptcies }}{100 \text { KPop }}\right)$

$-0.002^{* *} \quad-0.003^{* *}$

$(0.001) \quad(0.001)$

$1.187 \quad 0.470$

(1.536) (1.697)

$0.002 * * \quad 0.002 * *$

$(0.001) \quad(0.001)$

$0.045^{*} \quad 0.028$

$(0.019) \quad(0.017)$

-0.050 ** $\quad-0.048^{* *}$

$(0.014) \quad(0.012)$

$-0.003 \quad-0.003$

$(0.003) \quad(0.003)$

$0.008 \quad 0.020 * *$

(0.011) (0.012)

$-0.044 * * \quad-0.089$ **

$(0.020) \quad(0.019)$

0.076 ** $\quad 0.063^{* *}$

$(0.028) \quad(0.020)$

$-0.085 \quad-0.126$

$(0.138) \quad(0.142)$

$-0.402 \quad-0.153$

$(0.237) \quad(0.262)$

$0.388 *$

(0.242)

$-1.936 * *$

(0.280)

Yes Yes

$133 \quad 187$

0.63

0.16

${ }^{*}$ p-value $<.05 ; * *$ p-value $<.01$. Robust standard errors in parentheses. Sources: See text. 
Table 5. Fixed Effects, Random Effects, and the Hausman-Taylor Procedure

Dependent variable: Wage earner bankruptcies per 100,000 persons

\begin{tabular}{|c|c|c|}
\hline Fixed & Random & Hausman \\
\hline Effects & Effects & Taylor \\
\hline 0.004 & 0.02 & 0.004 \\
\hline$(0.01)$ & $(0.02)$ & $(0.01)$ \\
\hline-2.33 & 0.589 & -13.12 \\
\hline (12.60) & (15.89) & (11.67) \\
\hline 0.02 & 0.03 & 0.02 \\
\hline$(0.02)$ & $(0.02)$ & $(0.02)$ \\
\hline 0.20 & -0.49 & $0.87 *$ \\
\hline$(0.62)$ & $(0.61)$ & $(0.52)$ \\
\hline$-3.78^{* *}$ & -0.94 & $-3.06^{* *}$ \\
\hline$(0.87)$ & $(0.57)$ & $(0.86)$ \\
\hline $0.39 * *$ & 0.15 & 0.14 \\
\hline$(0.12)$ & $(0.15)$ & $(0.34)$ \\
\hline-0.10 & -0.38 & -0.23 \\
\hline$(1.76)$ & $(0.27)$ & $(0.90)$ \\
\hline-0.99 & $-0.87 *$ & -0.14 \\
\hline$(0.86)$ & $(0.48)$ & $(1.00)$ \\
\hline $0.31 *$ & 0.46 & 0.11 \\
\hline \multirow[t]{9}{*}{$(0.55)$} & $(0.31)$ & $(0.59)$ \\
\hline & 7.83 & -7.12 \\
\hline & $(7.27)$ & $(8.73)$ \\
\hline & -2.22 & -4.26 \\
\hline & $(5.22)$ & (16.15) \\
\hline & 17.12 & -8.44 \\
\hline & (13.72) & (63.23) \\
\hline & -20.39 & -96.1 \\
\hline & (13.24) & $(75.50)$ \\
\hline Yes & Yes & No \\
\hline 133 & 133 & 125 \\
\hline \multirow[t]{2}{*}{0.04} & 0.53 & 0.93 \\
\hline & 76.4 & 50.5 \\
\hline
\end{tabular}

Year Effects?

Yes

$\mathrm{N}$

R2

Real Per Capita Income

Income Growth

Loan to Income Ratio

Registered Vehicles per 100 Persons

Church Members (\% of Pop.)

Divorces per 1,000 Persons

Urban (\% of Pop.)

Homestead Exemption/Per Capita Real Estate. Wealth

Personal Exemption/Per Capita Personal Wealth

Max. Interest Rate

State Has Small Loan Law

Severe Garnishment Law

Lenient Garnishment Law

Wald Chi-Square

* p-value<.05; ** p-value<.01. Robust standard errors in parentheses. $\mathrm{N}=125$ in Hausman-Taylor specifications because the procedure requires a balanced panel.

Sources: See text. 
Table 6. Fixed Effect Vector Decomposition

Dependent variable: Wage earner bankruptcies per 100,000 persons

\begin{tabular}{|c|c|c|c|c|}
\hline & $(1)$ & $(2)$ & (3) & (4) \\
\hline \multirow[t]{2}{*}{ Real Per Capita Income } & 0.01 & $0.02 *$ & $0.03 *$ & -0.01 \\
\hline & $(0.01)$ & $(0.01)$ & $(0.01)$ & $(0.03)$ \\
\hline \multirow[t]{2}{*}{ Income Squared } & & & & 0.01 \\
\hline & & & & $(0.01)$ \\
\hline \multirow[t]{2}{*}{ Income Growth } & 13.71 & 7.84 & 3.15 & 12.72 \\
\hline & $(16.94)$ & $(12.63)$ & $(14.21)$ & $(16.43)$ \\
\hline \multirow[t]{2}{*}{ Growth Squared } & & & & -0.53 \\
\hline & & & & $(23.41)$ \\
\hline \multirow[t]{2}{*}{ Loan to Income Ratio (x 1,000) } & $0.03 * *$ & $0.03 * *$ & $0.02 * *$ & $0.03^{* *}$ \\
\hline & $(0.01)$ & $(0.01)$ & $(0.01)$ & $(0.01)$ \\
\hline \multirow[t]{2}{*}{ Registered Vehicles per 100 Persons } & $0.49 *$ & $0.43^{* *}$ & -0.08 & $0.68^{* *}$ \\
\hline & $(0.23)$ & $(0.16)$ & $(0.18)$ & $(0.17)$ \\
\hline \multirow[t]{2}{*}{ Church Members (\% of Pop.) } & $-2.32 * *$ & $-3.11 * *$ & & $-3.22 * *$ \\
\hline & $(0.189)$ & $(0.24)$ & & $(0.26)$ \\
\hline \multirow[t]{2}{*}{ Catholics ( $\%$ of Pop.) } & & & $-1.88^{* *}$ & \\
\hline & & & $(0.19)$ & \\
\hline \multirow[t]{2}{*}{ Divorces per 1,000 Persons } & 0.22 & $0.31 * *$ & $0.19 *$ & $0.31 * *$ \\
\hline & $(0.13)$ & $(0.09)$ & $(0.09)$ & $(0.10)$ \\
\hline \multirow[t]{2}{*}{ Urban (\% of Pop.) } & $1.23^{* *}$ & $0.57 * *$ & $1.26^{* *}$ & $0.74 * *$ \\
\hline & $(0.149)$ & $(0.09)$ & $(0.14)$ & 0.12 \\
\hline \multirow{2}{*}{ Level of Homestead Exemption } & $-0.001 * *$ & & & \\
\hline & $(0.001)$ & & & \\
\hline \multirow{3}{*}{$\begin{array}{l}\text { Homestead Exemption/Per Capita Real Estate } \\
\text { Wealth }\end{array}$} & & $132 * *$ & $-088 * *$ & $-143 * *$ \\
\hline & & -1.02 & -0.00 & -1.45 \\
\hline & & $(0.15)$ & $(0.15)$ & $(0.16)$ \\
\hline \multirow[t]{2}{*}{ Level of Personal Exemption } & $0.014 * *$ & & & \\
\hline & $(0.002)$ & & & \\
\hline \multirow[t]{2}{*}{ Personal Exemption/Per Capita Personal Wealth } & & $0.67 * *$ & $0.46^{*}$ & $0.76^{* *}$ \\
\hline & & $(0.23)$ & $(0.23)$ & $(0.23)$ \\
\hline \multirow[t]{2}{*}{ State Has Small Loan Law } & $-6.56^{*}$ & -4.00 & $-32.44 * *$ & $-4.70 *$ \\
\hline & $(3.50)$ & $(2.53)$ & $(3.11)$ & $(2.61)$ \\
\hline \multirow[t]{2}{*}{ Max. Legal Interest Rate } & $18.39 * *$ & $12.99 * *$ & $8.41 * *$ & $13.71 * *$ \\
\hline & $(1.56)$ & $(1.21)$ & $(1.20)$ & $(1.28)$ \\
\hline \multirow[t]{2}{*}{ Severe Garnishment Law } & $29.55^{* *}$ & $19.74 * *$ & $33.37 * *$ & $21.44 * *$ \\
\hline & $(3.08)$ & $(2.63)$ & $(3.24)$ & $(2.69)$ \\
\hline \multirow[t]{2}{*}{ Lenient Garnishment Law } & -0.88 & $-16.96^{* *}$ & -1.70 & $-14.80 * *$ \\
\hline & $(2.79)$ & $(2.53)$ & $(2.68)$ & $(2.55)$ \\
\hline $\mathrm{N}$ & 133 & 133 & 133 & 133 \\
\hline $\mathrm{R}^{2}$ & 0.93 & 0.93 & 0.92 & 0.90 \\
\hline Year Effects? & Yes & Yes & Yes & Yes \\
\hline
\end{tabular}


* p-value $<.05 ; * *$ p-value $<.01$. Robust standard errors in parentheses. Sources: See text. 
Figure 1. The National Bankruptcy Rate, U.S. 1899-1970

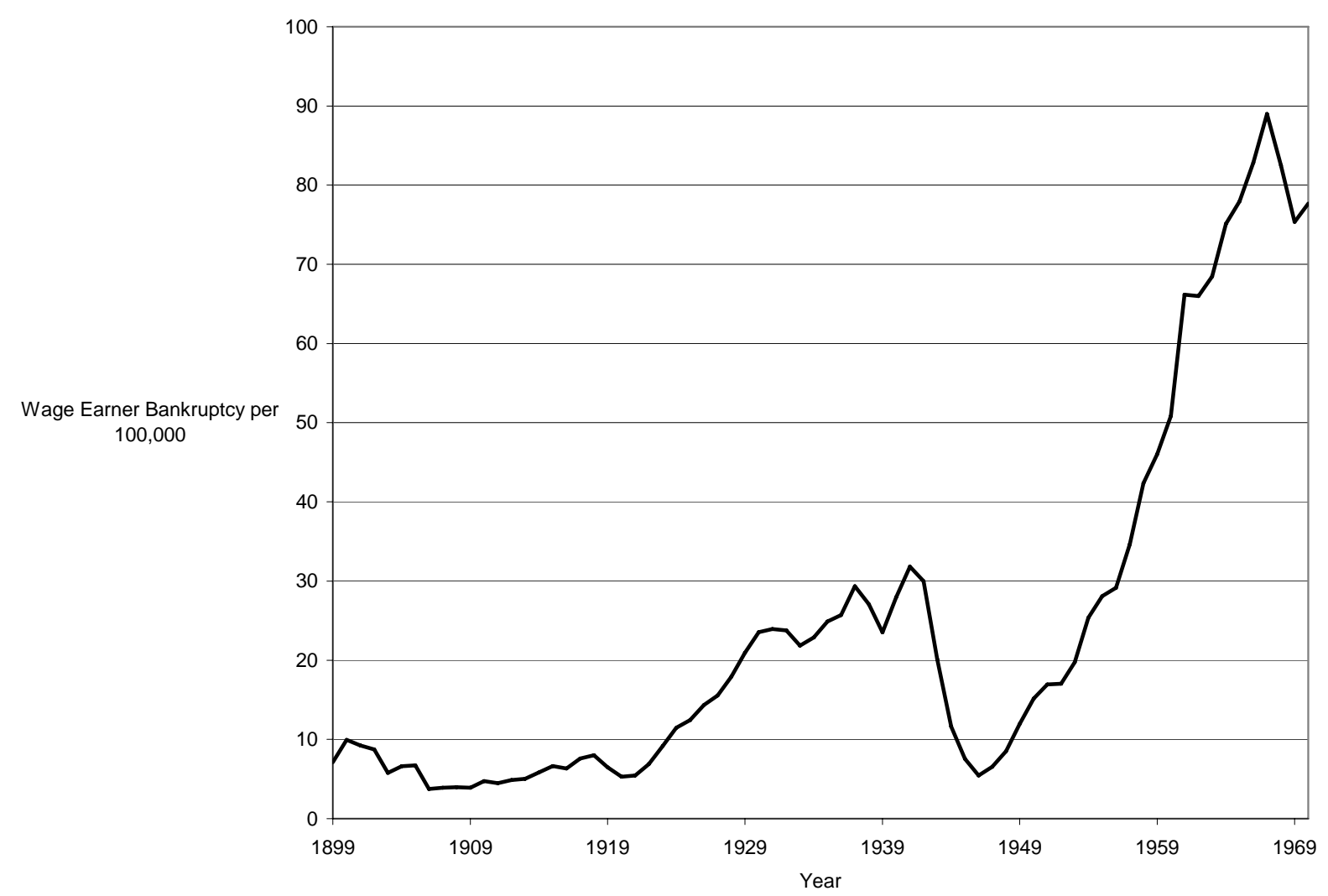

Sources: 1899-1938: US DOJ (various years); 1939-1997: US Bureau of the Census (various years). 
Figure 2. Bankruptcy and State per Capita Income

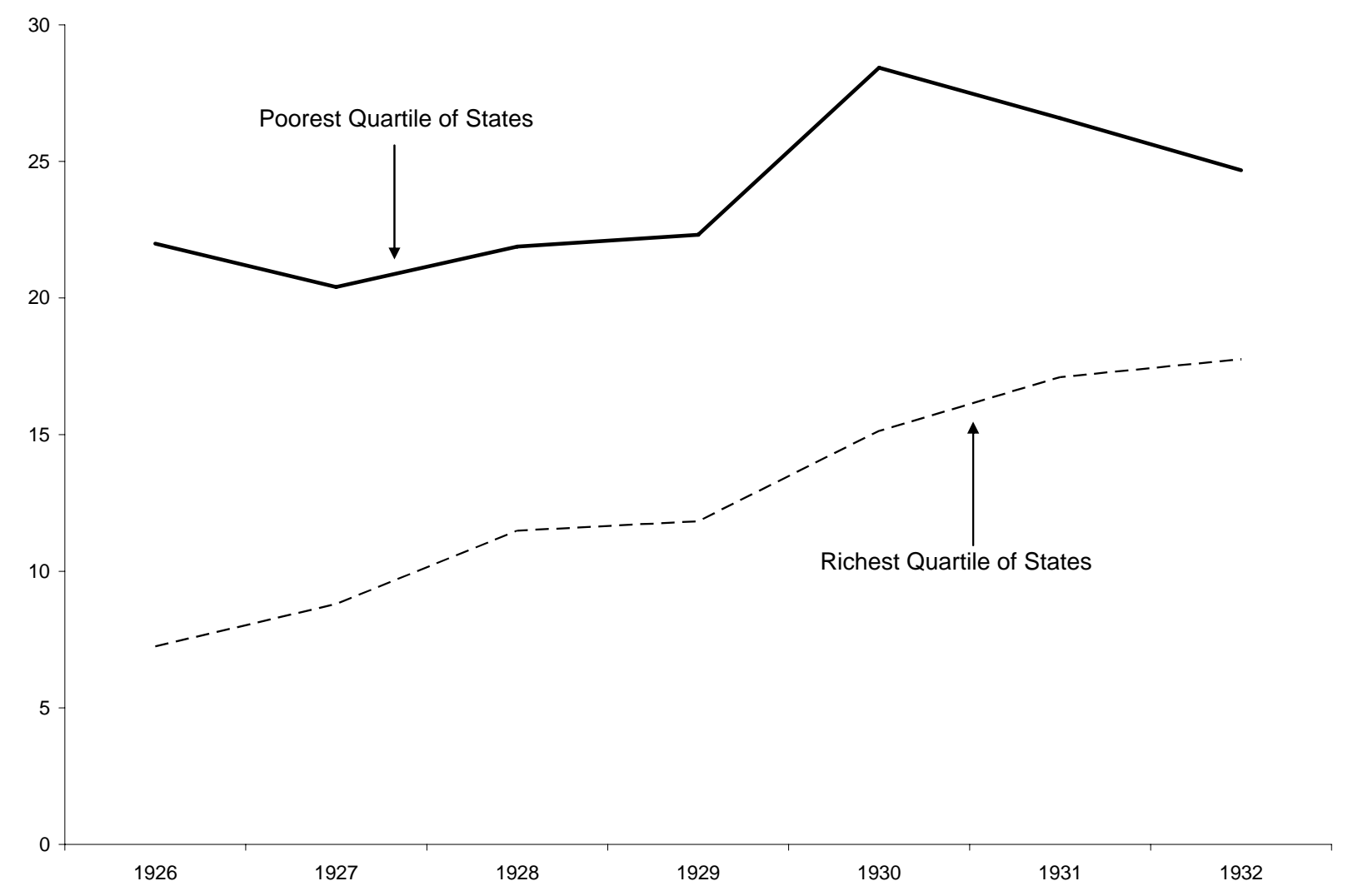

Sources: See text. 
Figure 3. Bankruptcy and Church Membership

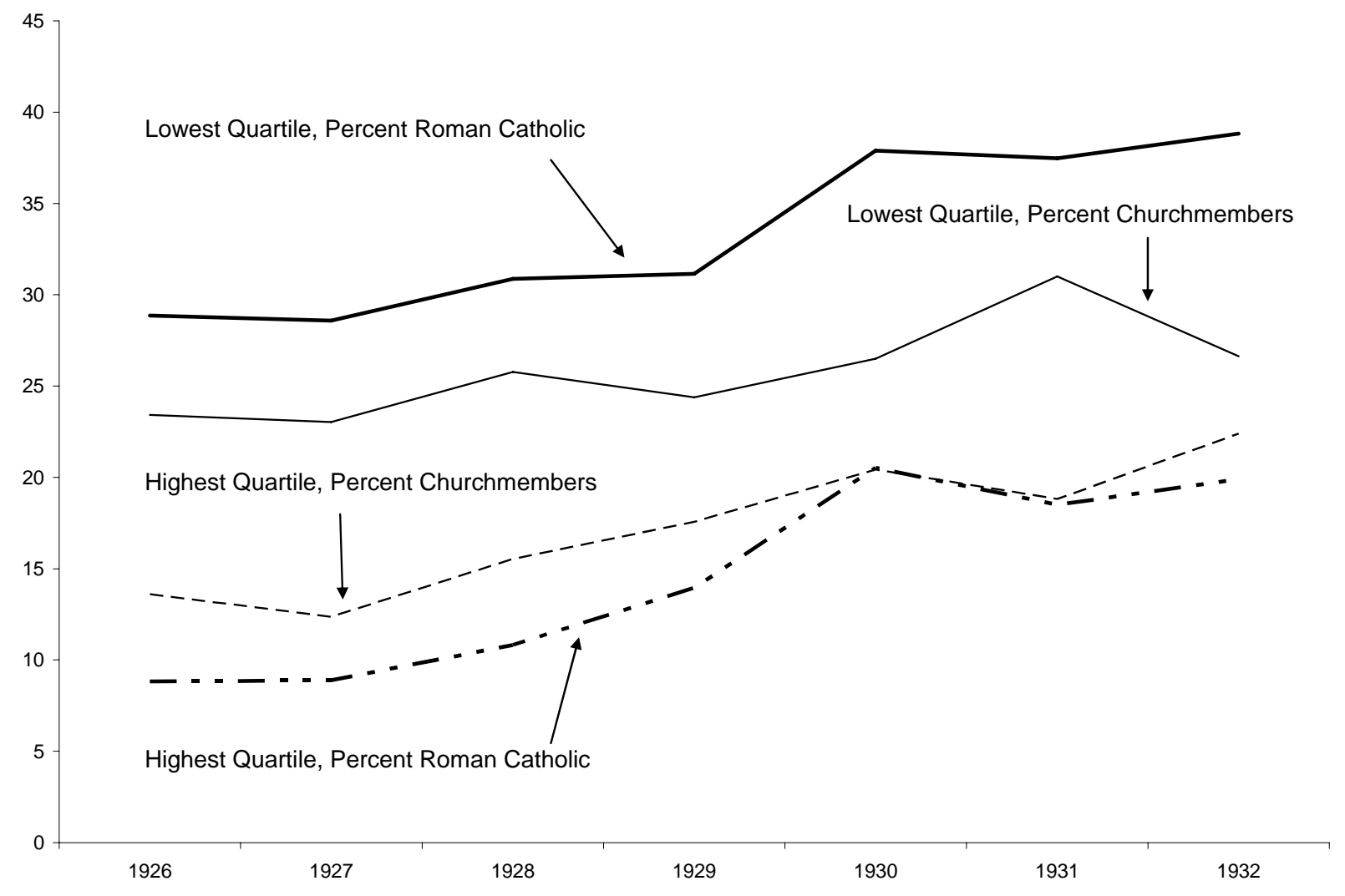


Figure 4. Bankruptcy and Exemptions

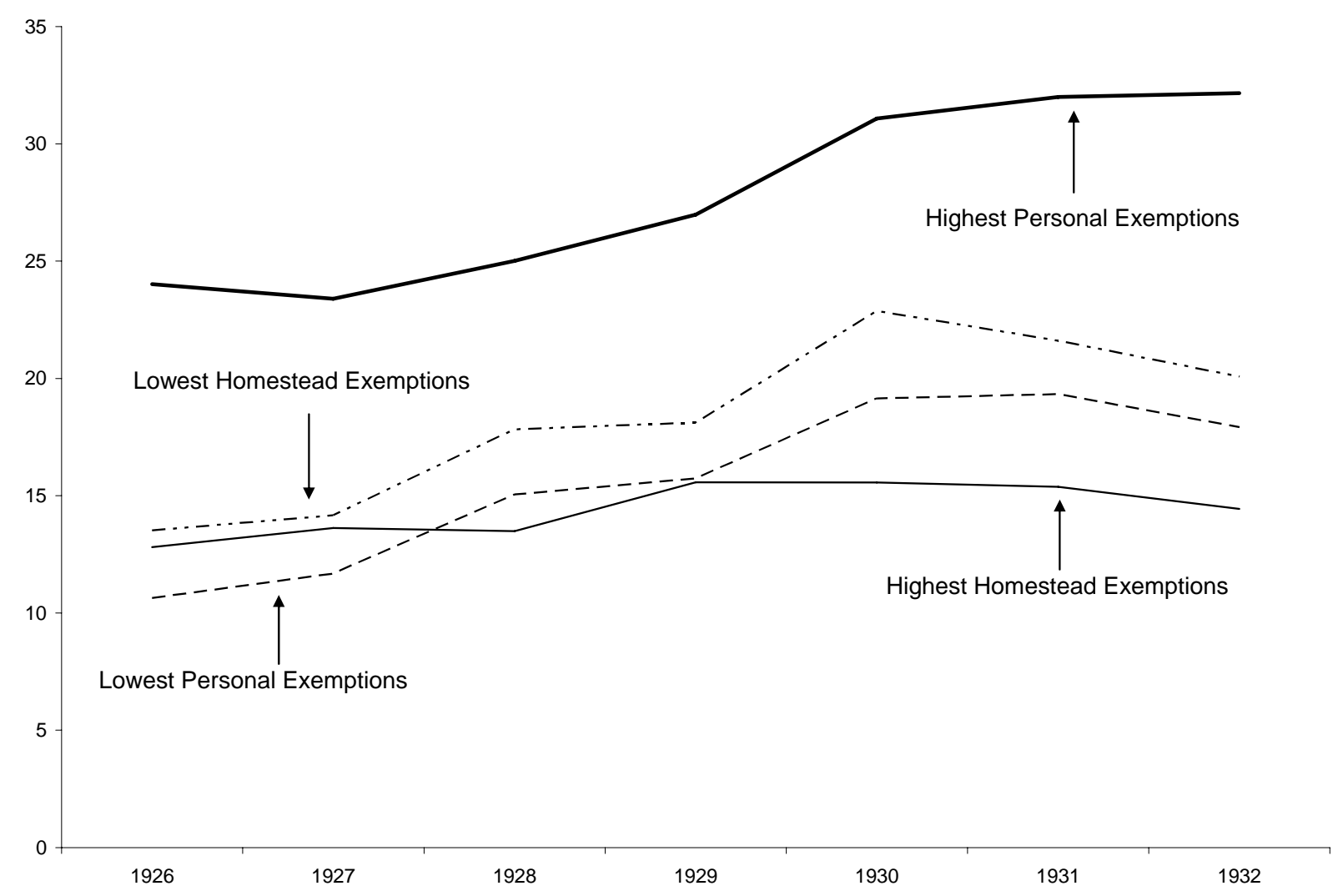

Source: See text. 
Figure 5. Bankruptcy and the Legal Maximum Interest Rate

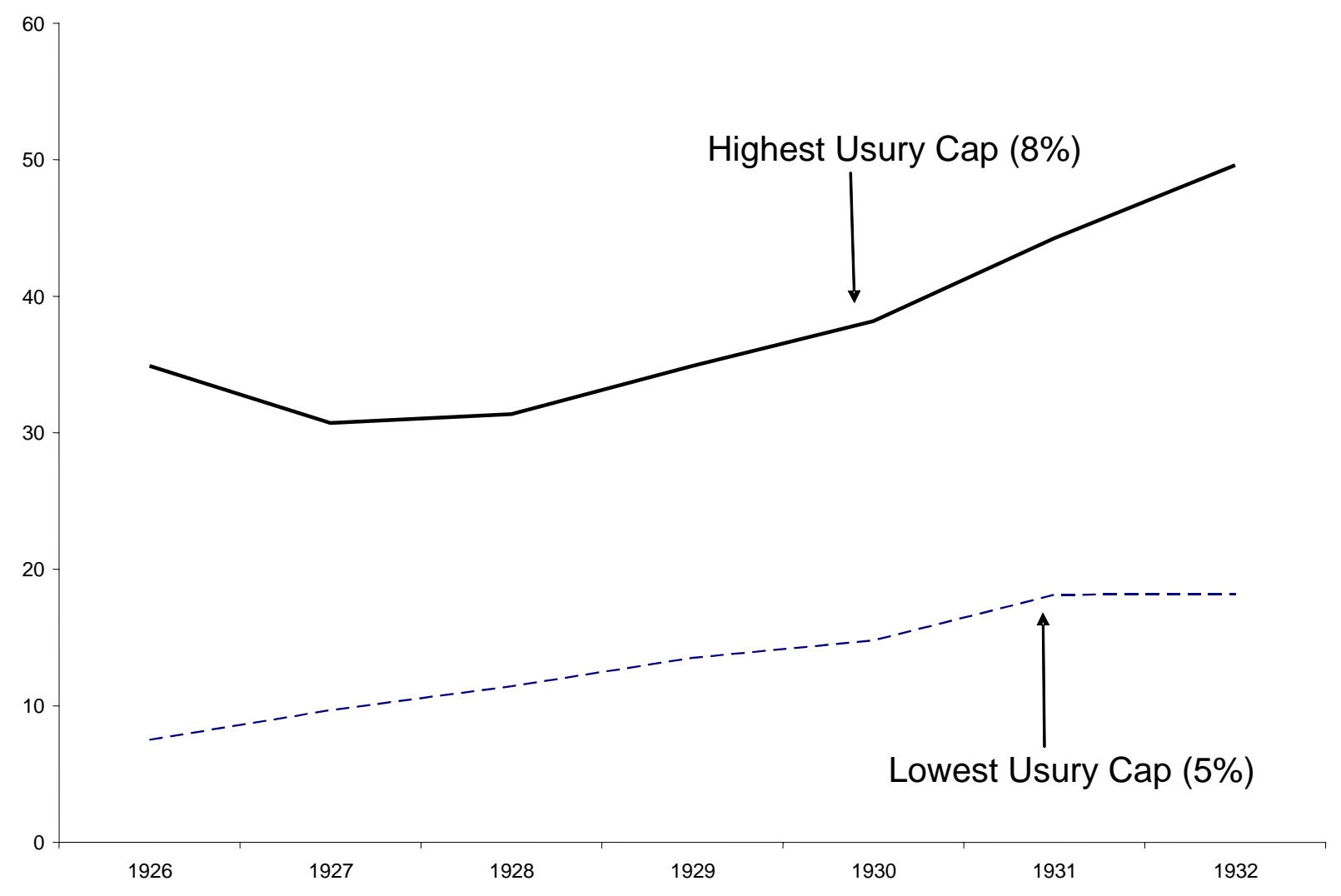


Figure 6. Bankruptcy and the Existence of a Small Loan Law

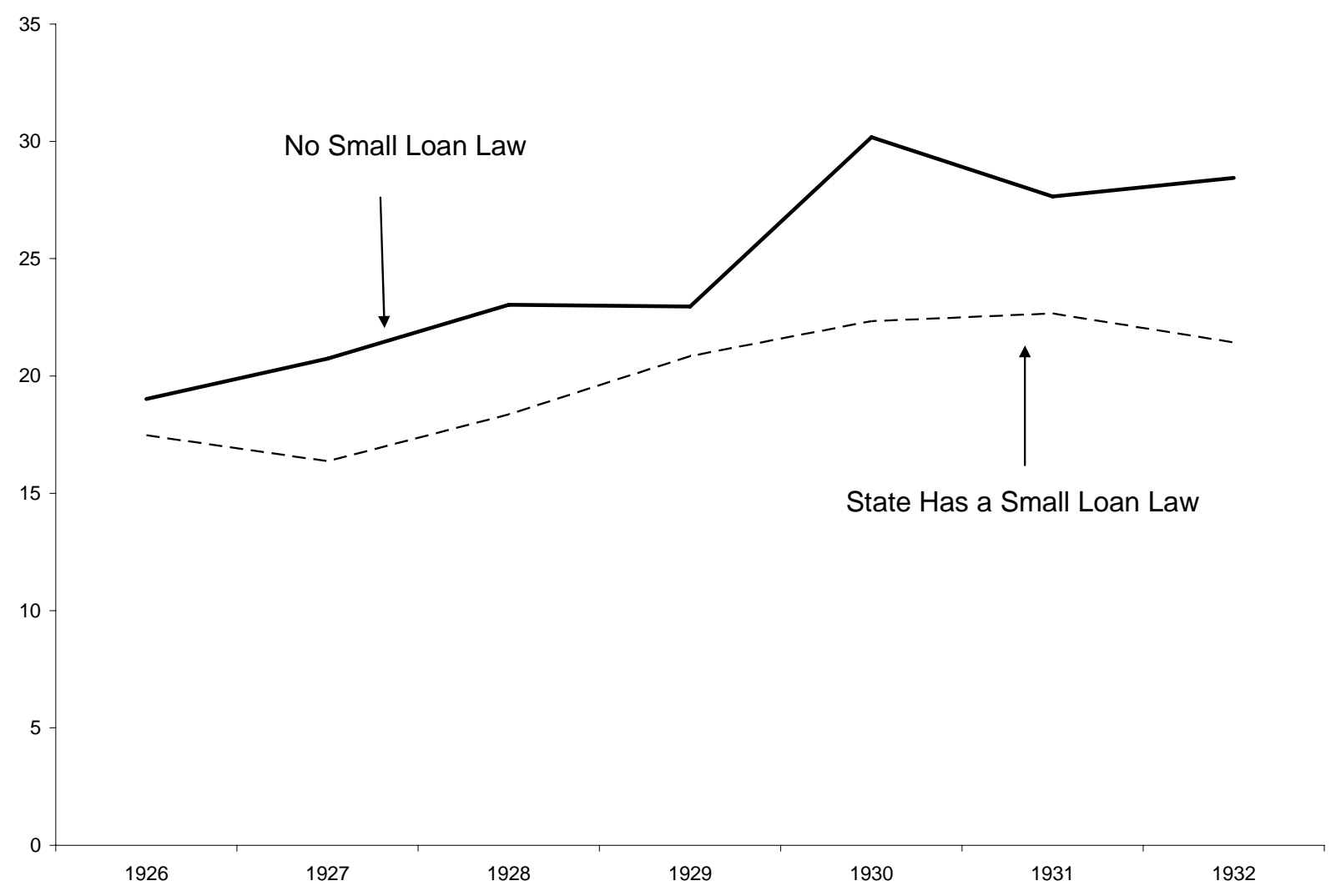

Sources: See text. 
Figure 7. Bankruptcy and Garnishment Law

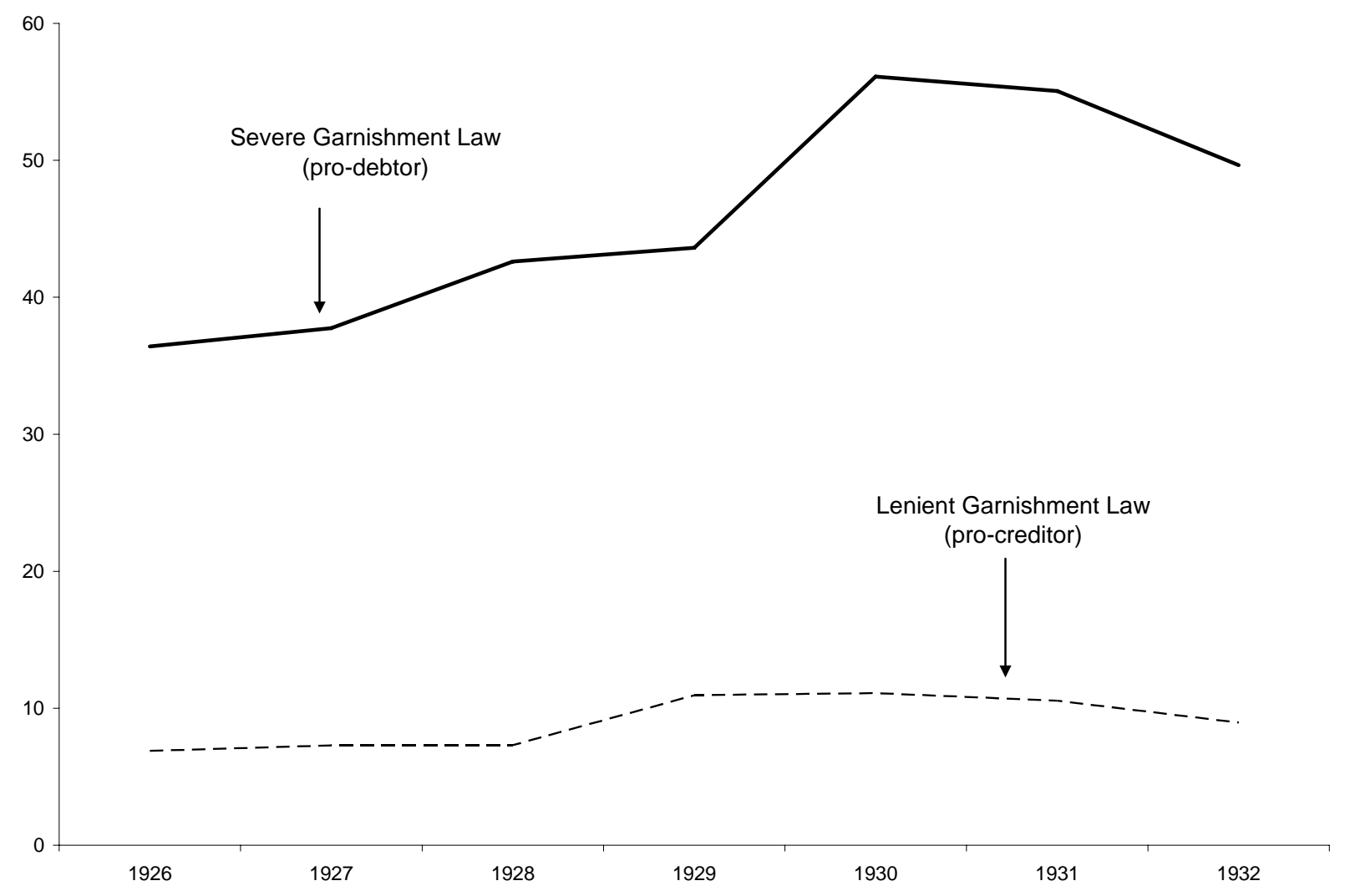

Sources: See text. 